University of Nebraska - Lincoln

DigitalCommons@University of Nebraska - Lincoln

MANTER: Journal of Parasite Biodiversity

Parasitology, Harold W. Manter Laboratory of

7-21-2017

\title{
Checklist of Helminths of Bats from Mexico and Central America
}

\author{
F. Agustín Jiménez \\ Southern Illinois University Carbondale, agustinjz@zoology.siu.edu \\ Juan M. Caspeta-Mandujano \\ Universidad Autónoma del Estado de Morelos, caspeta@uaem.mx
}

Said B. Ramírez-Chávez

Universidad Autónoma del Estado de Morelos

Silvia E. Ramírez-Díaz

Universidad Autónoma del Estado de Morelos

Marissa G. Juárez-Urbina

Universidad Autónoma del Estado de Morelos

See next page for additional authors

Follow this and additional works at: https://digitalcommons.unl.edu/manter

Part of the Biodiversity Commons, Parasitology Commons, and the Zoology Commons

Jiménez, F. Agustín; Caspeta-Mandujano, Juan M.; Ramírez-Chávez, Said B.; Ramírez-Díaz, Silvia E.; Juárez-Urbina, Marissa G.; Peralta-Rodríguez, Jorge L.; and Guerrero, José A., "Checklist of Helminths of Bats from Mexico and Central America" (2017). MANTER: Journal of Parasite Biodiversity. 8.

https://digitalcommons.unl.edu/manter/8

This Article is brought to you for free and open access by the Parasitology, Harold W. Manter Laboratory of at DigitalCommons@University of Nebraska - Lincoln. It has been accepted for inclusion in MANTER: Journal of Parasite Biodiversity by an authorized administrator of DigitalCommons@University of Nebraska - Lincoln. 


\section{Authors}

F. Agustín Jiménez, Juan M. Caspeta-Mandujano, Said B. Ramírez-Chávez, Silvia E. Ramírez-Díaz, Marissa G. Juárez-Urbina, Jorge L. Peralta-Rodríguez, and José A. Guerrero 


\title{
Checklist of Helminths of Bats from Mexico and Central America
}

\author{
F. Agustín Jiménez, ${ }^{1}$ Juan M. Caspeta-Mandujano, ${ }^{2}$ Said B. Ramírez-Chávez, ${ }^{2}$ \\ Silvia E. Ramírez-Díaz, ${ }^{2}$ Marissa G. Juárez-Urbina, ${ }^{2}$ Jorge L. Peralta-Rodríguez, ${ }^{2}$ \\ and José A. Guerrero² \\ 1 Department of Zoology, Southern Illinois University, Carbondale, Illinois, 62901-6501, USA \\ 2 Universidad Autónoma del Estado de Morelos, Facultad de Ciencias Biológicas y Centro de Investigaciones \\ Biológicas, Laboratorio de Parasitología, Avenida Universidad 1001, Colonia Chamilpa, CP 62209, Cuernavaca, \\ Morelos, México
}

Corresponding author: Juan M. Caspeta-Mandujano, email caspeta@uaem.mx

\begin{abstract}
Based on original data obtained from fieldwork conducted from January 2008 to December 2015 and from previous records from published accounts, an updated checklist of helminth parasites of bats from Mexico and Central America is presented. The checklist has been organized in four ways, first as a helminth-host list in the state of Morelos, second as a helminth-host list with taxonomic and geographic distributional information, third as a bat-helminth list with references, and last, as a summary of the host-helminth association. A total of 105 records and 67 helminth taxa (26 trematodes, 4 cestodes, and 37 nematodes [33 adult and 5 larvae]) in 27 bat species from the families Emballonuridae, Molossidae, Mormoopidae, Natalidae, Phyllostomidae, and Vespertilionidae are presented for Mexico and Central America. Eight species of helminths are unique to Central America and ten species occur in both Mexico and the isthmus. From the helminths recorded in Mexico, 34 helminth species in 19 species of bats are present in the state of Morelos. The helminth diversity represents 58\% of the total recorded thus far in Mexico, yet the diversity of bats intensively surveyed for parasites in the country represents roughly $14 \%$ of the diversity of chiropterans present. This evidence suggests that these intensive examinations are necessary to complete the helminthological record for bats, especially in areas of high endemism.
\end{abstract}

Keywords: helminths, trematodes, cestodes, nematodes, bats, Chiroptera, geographical distribution, Mexico

\section{Introduction}

Mexico is located in the transition between the Nearctic and Neotropical realms; it features a complex topography and almost all types of climates within its territory. As a consequence this country hosts an enormous biological diversity (Sarukhán et al., 2009). This diversity has been extensively documented for vertebrates, arthropods, and plants (Medellín, 2003; Rzedowski, 2006; Fernández et al., 2014; Trejo-Salazar et al., 2015; Santibáñez-López et al., 2016). With respect to the diversity of invertebrates other than arthropods, the study of helminths is asymmetrically represented since most studies have focused on fish-dwelling helminths (Salgado-Maldonado, 2006), followed by helminths of reptiles (Paredes-León et al., 2008). In contrast, few records document the diversity of helminths among the 545 species of mammals occurring in the Mexican territory (Ceballos and Arroyo-Cabrales, 2012). From that total, only 25 species have been extensively surveyed for helminths across the territory, with sparse records for roughly 135 species of mammals (García-Prieto et al., 2012; GuzmánCornejo et al., 2012; Jiménez, 2012). It is apparent that the 
inventory of helminths of wild mammals is still incomplete (García-Prieto et al., 2012; García-Prieto et al., 2014). The helminth fauna of vertebrates from Central America shows a similar trend (Rodriguez-Ortíz et al., 2004).

Bats (Order Chiroptera) are one of the most successful groups of mammals, including about 1,100 recognized species worldwide, with 138 occurring in Mexico (Ceballos and Arroyo-Cabrales, 2012). Bats are reservoirs to a great number of pathogens including eukaryote, viral, and bacterial organisms that are known etiological agents of disease (Ubelaker et al., 1979; Hayman et al., 2013; Mühldorfer, 2013). The distribution of these parasites and pathogens in bats and their patterns of association are poorly understood (Presley et al., 2015), even when their effects on populations of chiropterans are considered good indicators of stress (Cottontail et al., 2009).

In Mexico, parasitological studies in the Order Chiroptera began in the late 1930s with the report and description of parasites of four species of bats from caves in $\mathrm{Yu}$ catan (Chitwood, 1938; Stunkard, 1938). These early records documented the presence of metazoans infecting the Jamaican fruit-eating bat, Artibeus jamaicensis Leach, 1821; the Pallas' long-tongued bat, Glossophaga soricina (Pallas, 1766); the little small-eared bat, Micronycteris microtis Miller, 1898; and the Mexican funnel-eared bat, Natalus stramineus Gray 1838 ( $N$. mexicanus). The species of helminths recorded include the nematodes Litomosoides sp. (= Litomosoides chitwoodi Bain et al., 2003), Bidigiticauda vivipara Chitwood, 1938, and Cheiropteronema globocephala Chitwood, 1938 in the Jamaican fruit-eating bat; Litomosoides hamletti Chitwood, 1938 in the Pallas' long-tongued bat Capillaria sp. and Anenterotrema auritum Stunkard, 1938 (nematode and trematode, respectively) in the little small-eared bat; and the trematodes Anenterotrema singulare Stunkard, 1938 and Parabascus yucatanense Chitwood, 1938 (= Parabascoides yucatanensis) and the nematodes Tricholeiperia carnegiensis Chitwood, 1938, T. pearsei Chitwood, 1938, and Seuratum cancellatum Chitwood, 1943 occurring in the Mexican funnel-eared bat.

\section{Scope}

Studies on helminth parasites from bats were continued by Caballero (1939; 1940a,b; 1942a,b; 1943a,b,c), Caballero and Zerecero (1951), García (1995); Pérez-Ponce de León et al. (1996), Guzmán-Cornejo et al. (2003), Falcón-Ordaz et al. (2006), Clarke (2008), Eslava (2005), Peralta-Rodríguez et al. (2012), Caspeta-Mandujano et al. $(2013,2015)$, and Jiménez et al. (2014). Since 2008 the team of the Laboratorio de Parasitología of the Universidad Autónoma del Estado de Morelos has monitored helminths from bats in the State of Morelos (Martínez, 2009; Peralta, 2009, 2012; Tapia, 2011; Ojeda, 2013; Galindo, 2014; Juárez, 2015; Ramírez, 2015; Ramírez, 2015 and Juárez, pers. comm.). That research was supported by a compilation of records on members of the
Nematoda, Cestoda, and Digenea occurring in bats and published until mid 2016, and included the sparse records generated from studies carried out in Central America. In the present manuscript we present a checklist of bat-dwelling helminths occurring in Mexico and Central America, and emphasize the diversity of helminths recorded in a small territory in central Mexico. The number of new species descriptions generated by this survey suggests that more intensive sampling across Mexico and Central America will asssist in discovering new species and characterizing their host and geographic distribution.

\section{Materials and Methods}

Using published records and unpublished information obtained from the fieldwork from 2008 to 2015, from 8 localities in the State of Morelos (Table 1; Figure 1), a checklist of the helminth parasites of bats in Mexico was generated. Helminth species are presented in taxonomical order arranged by phylum and then by family, followed by information of their host(s), state of the country of the record(s), site of infection, and reference(s).

A total of 18 bat species belonging to 6 families from 8 localities in the State of Morelos were examined for the presence of helminth parasites from January 2008 to December 2014 (Table 1). The collection of bat hosts was developed in different localities, covering the regions North, Center and South of the state; interestingly, these regions include Nearctic landscapes (i.e., pine and oak forest 2,000 $\mathrm{m}$ in elevation) and Neotropical dry forests. Bats were captured under Licencia de Colector Científico FAUT0211 (National Collecting Permit 0211) from the Secretaria del Medio Ambiente y Recursos Naturales (SEMARNAT) using mist nets placed near and at the entrances of roosts, such as mines, abandoned houses, occupied vegetation, and over water bodies. Nets were set between 18:00 and 22:00 hours, with the aim of capturing at least 10 individuals per species. Bats were removed from the mist net and placed in individual canvas bags for transport to the laboratory, where they were kept alive until their helminthological examination. This examination did not exceed 24 hr upon capture. Bats were killed following standard recommendations set forth by the American Society of Mammalogists (Sikes et al., 2011). The external surface, viscera, and musculature of each individual bat were examined under a stereomicroscope, and all the helminths encountered were counted (Gardner and Jiménez-Ruiz, 2009). Trematodes, cestodes, and nematodes were fixed in hot neutral $4 \%$ formalin. Trematodes and cestodes were used for morphological studies as whole mounts; therefore, the specimens were stained with Mayer's paracarmine, dehydrated using a graded alcohol series, cleared in methyl salicylate, and mounted in Canada balsam. Nematodes were cleared with glycerine for microscopic examination and stored in $70 \%$ ethanol. 


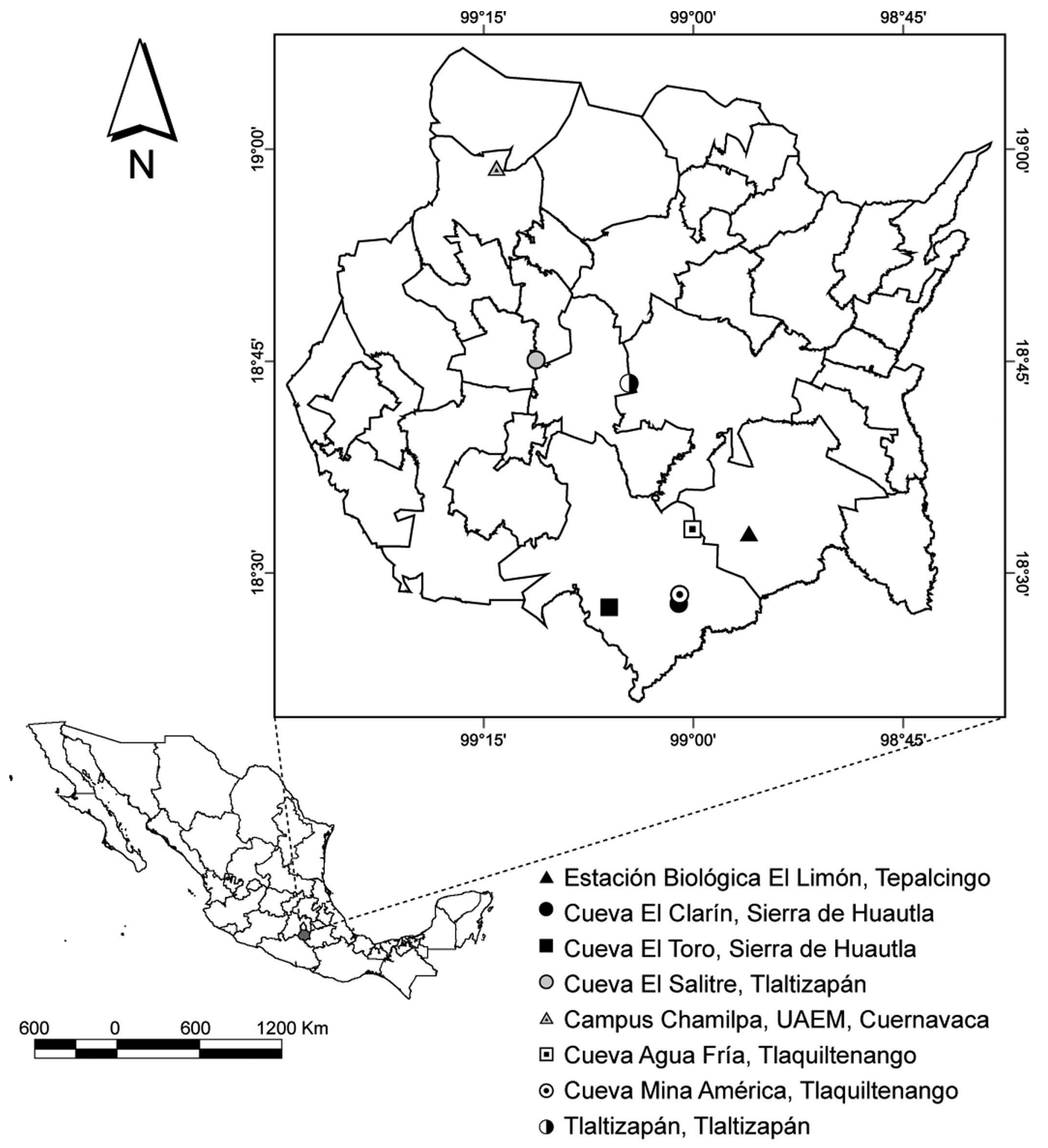

Figure 1. Eight fieldwork localities in the State of Morelos for helminth parasites of bats. 


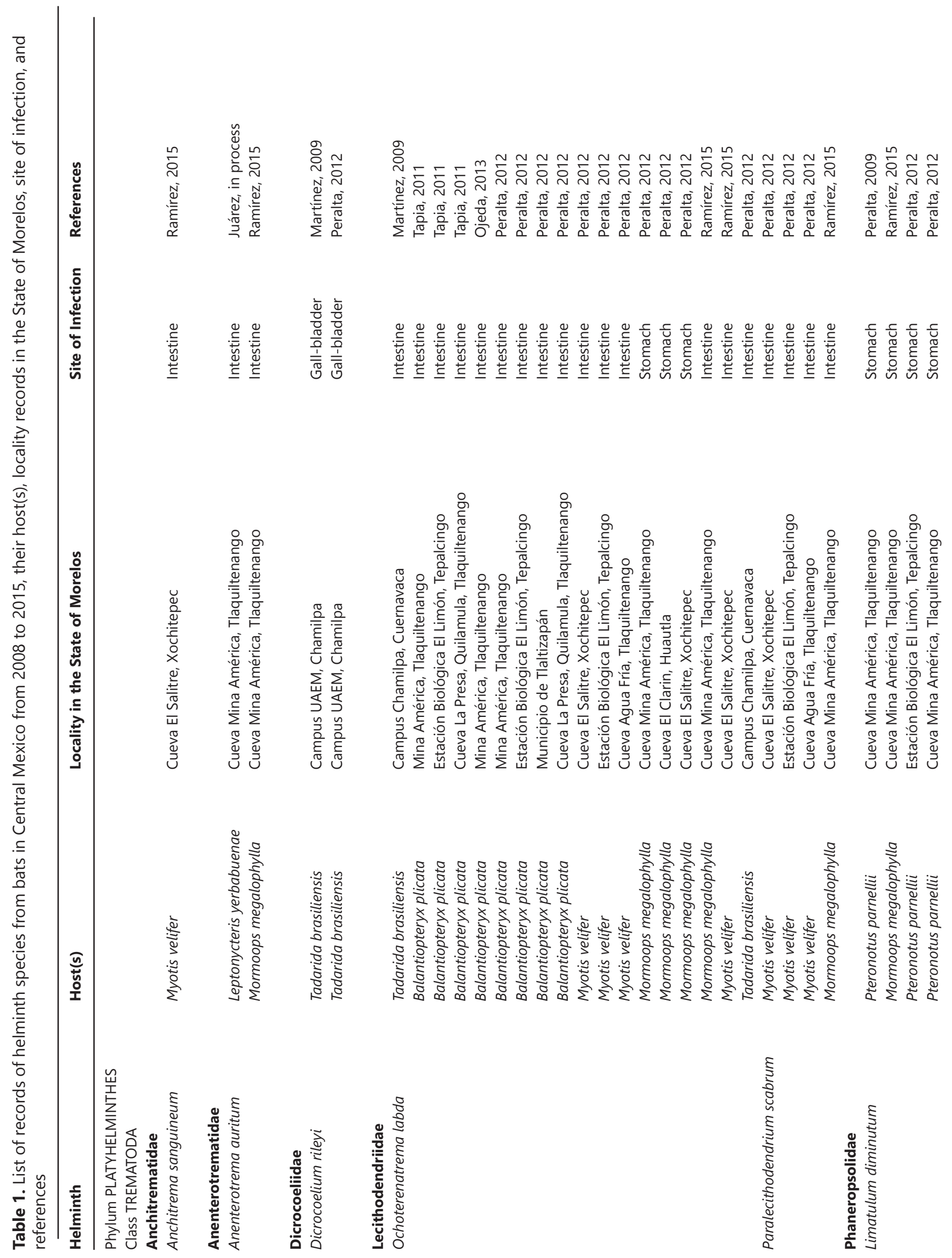




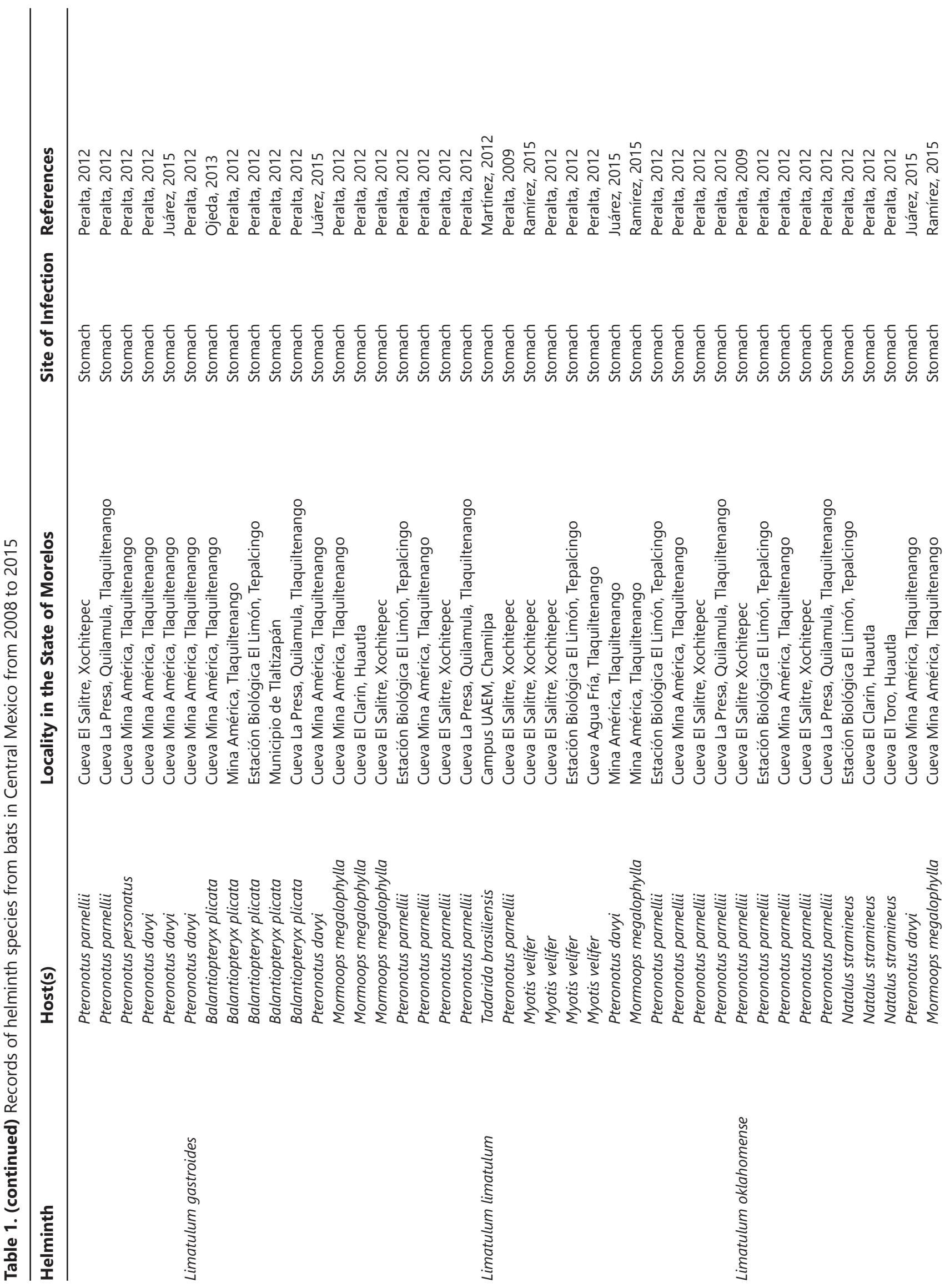




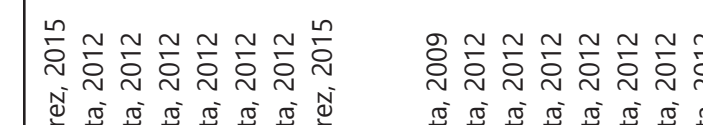

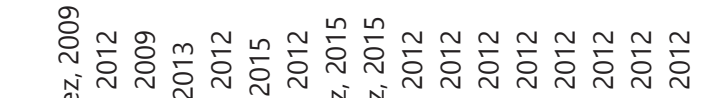

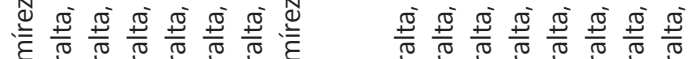

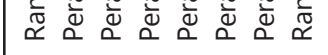
م.

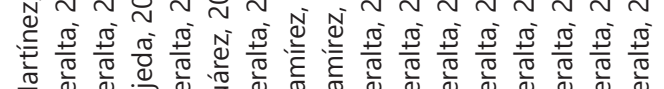

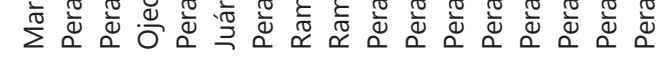

$\stackrel{2}{0}$

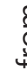

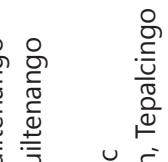

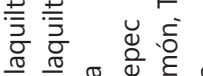

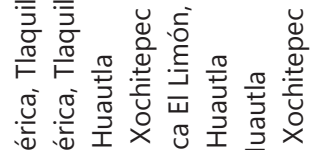
है है

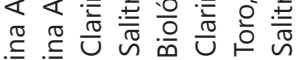

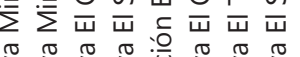

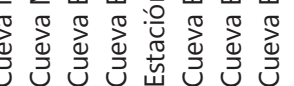

華

은

$\frac{d}{4}$

过

高

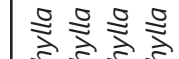

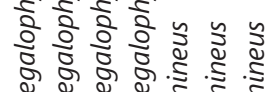
है है है है है है के

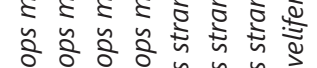

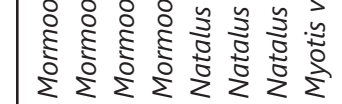
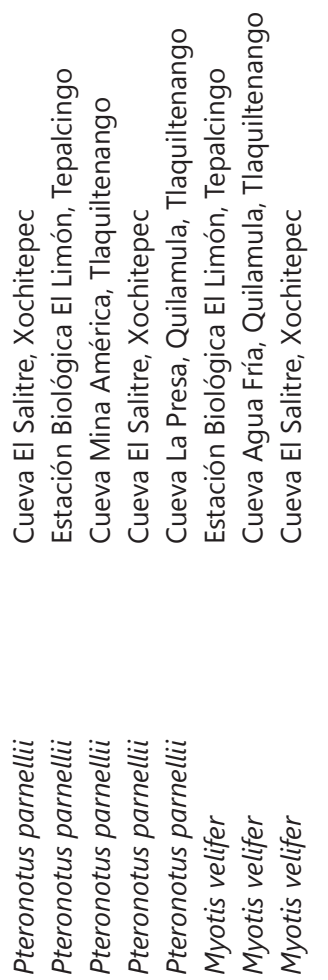
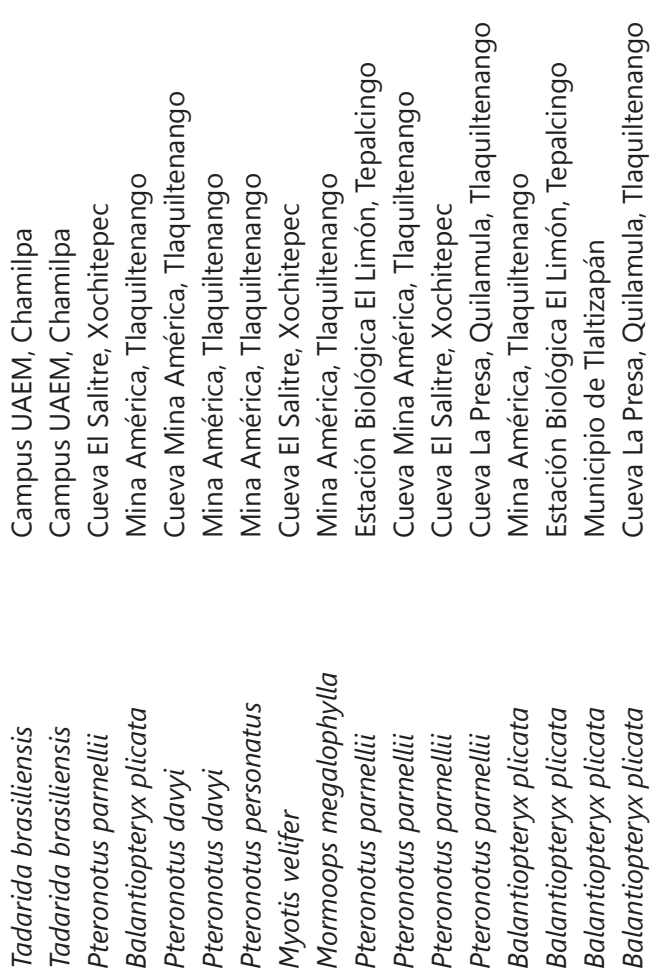

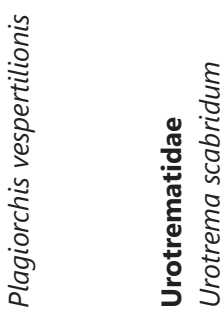




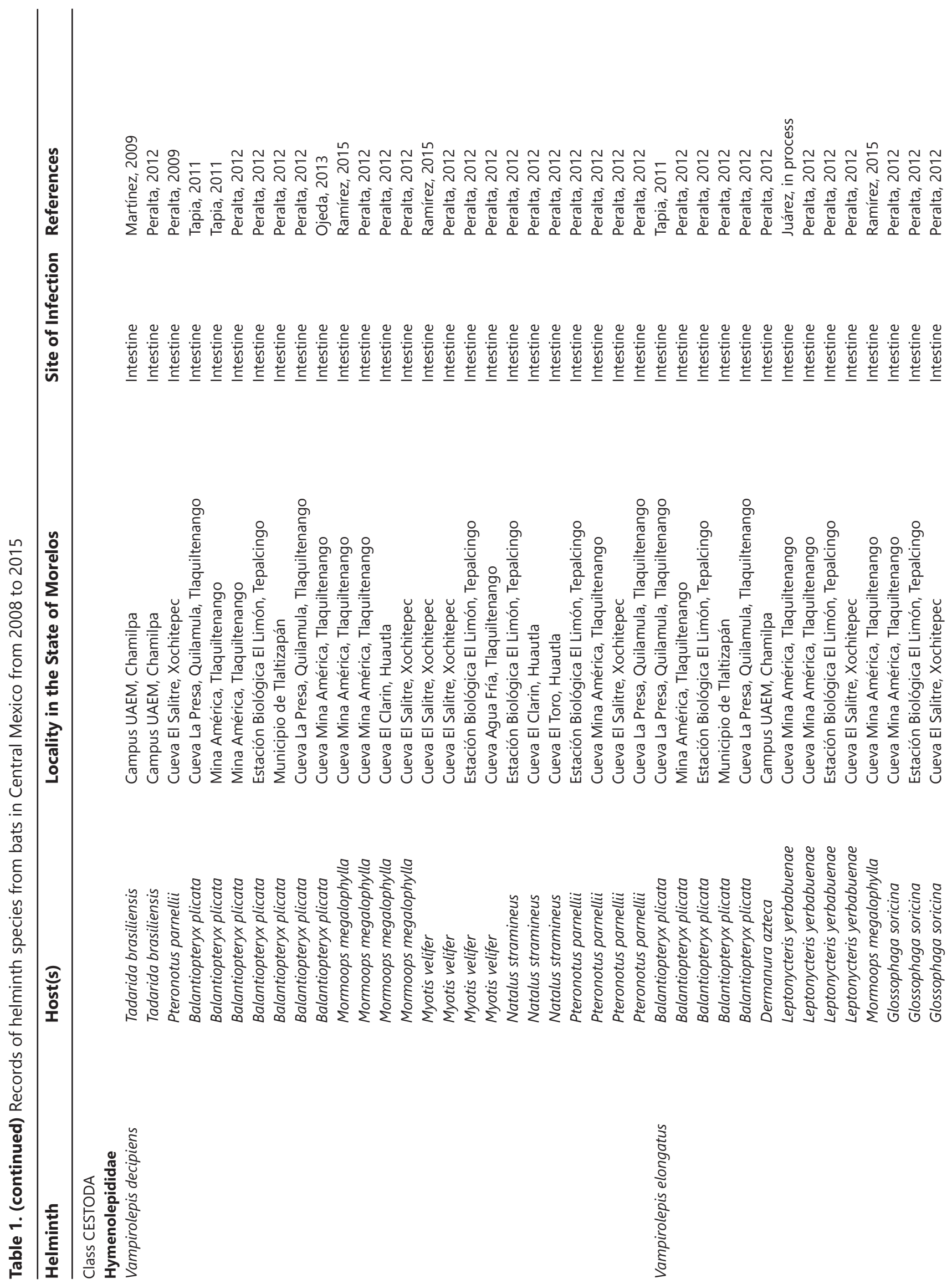




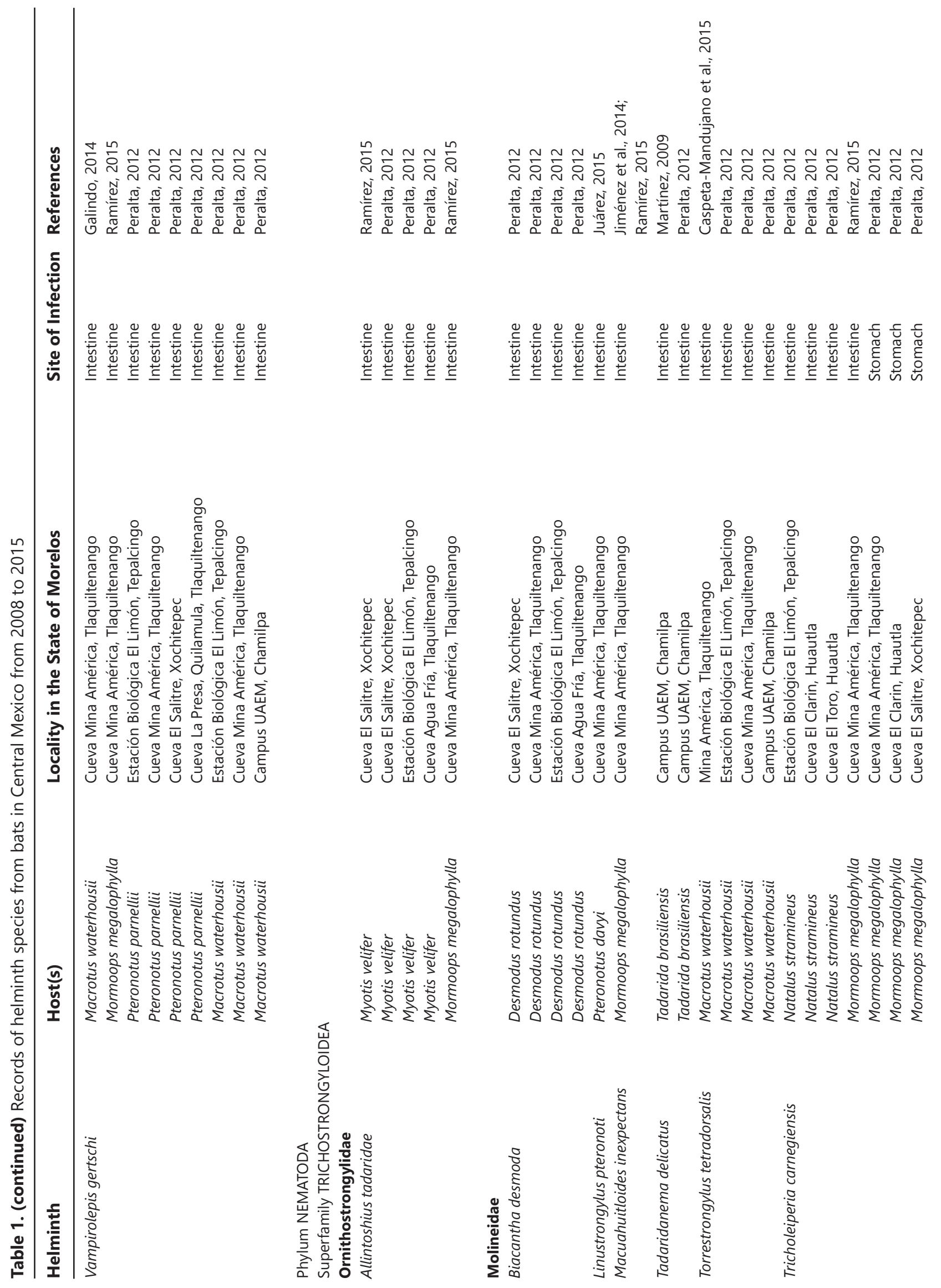




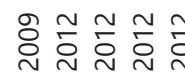
$\frac{\pi}{\frac{\pi}{\pi}} \frac{\pi}{\pi} \frac{\pi}{\pi} \frac{\pi}{\frac{\pi}{\pi}} \frac{\pi}{\frac{\pi}{\pi}}$

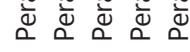

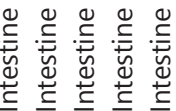

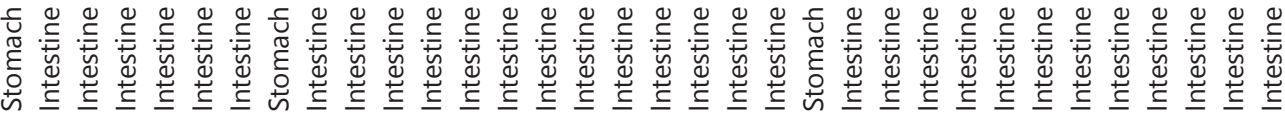

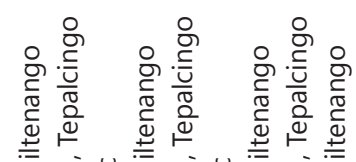

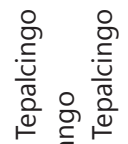

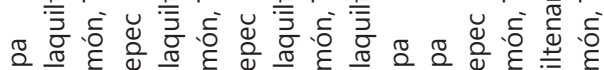

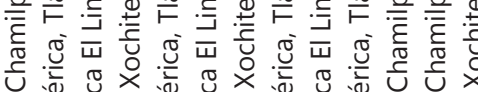

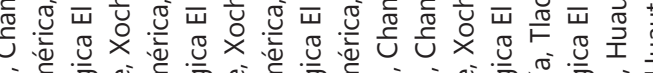

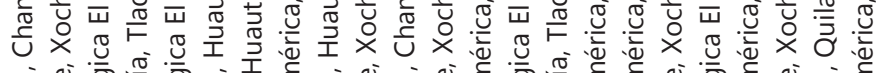

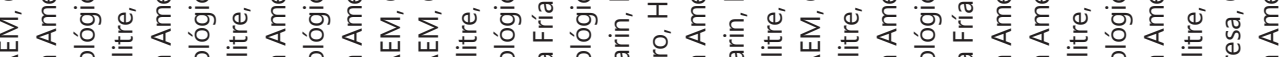

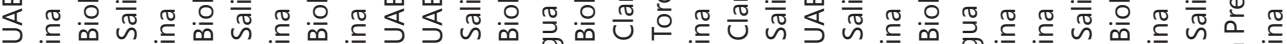

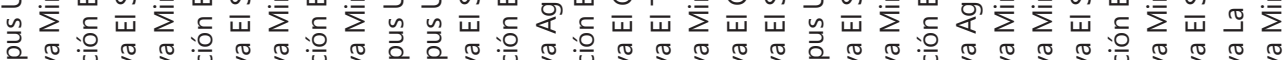

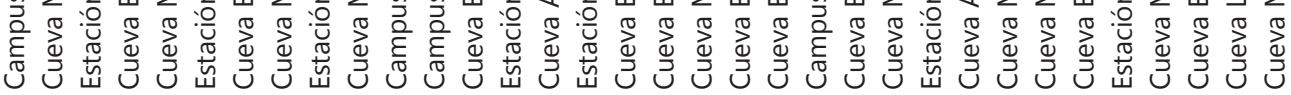

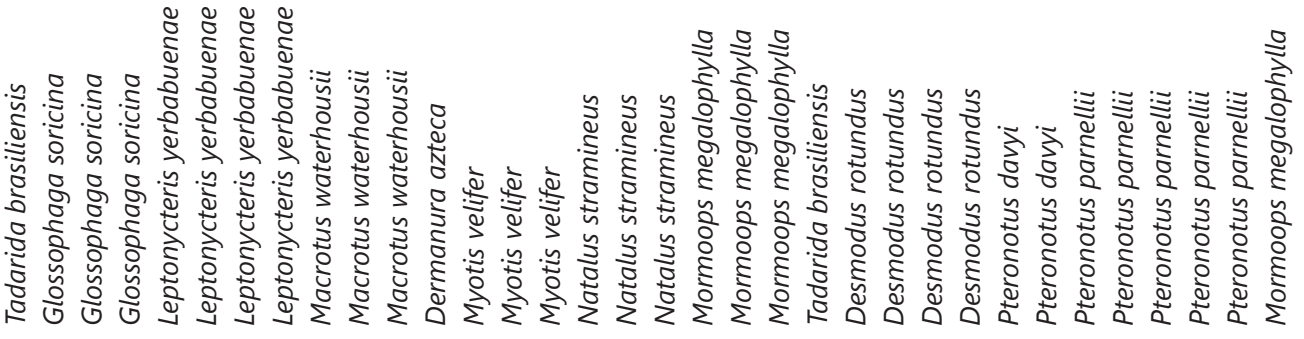




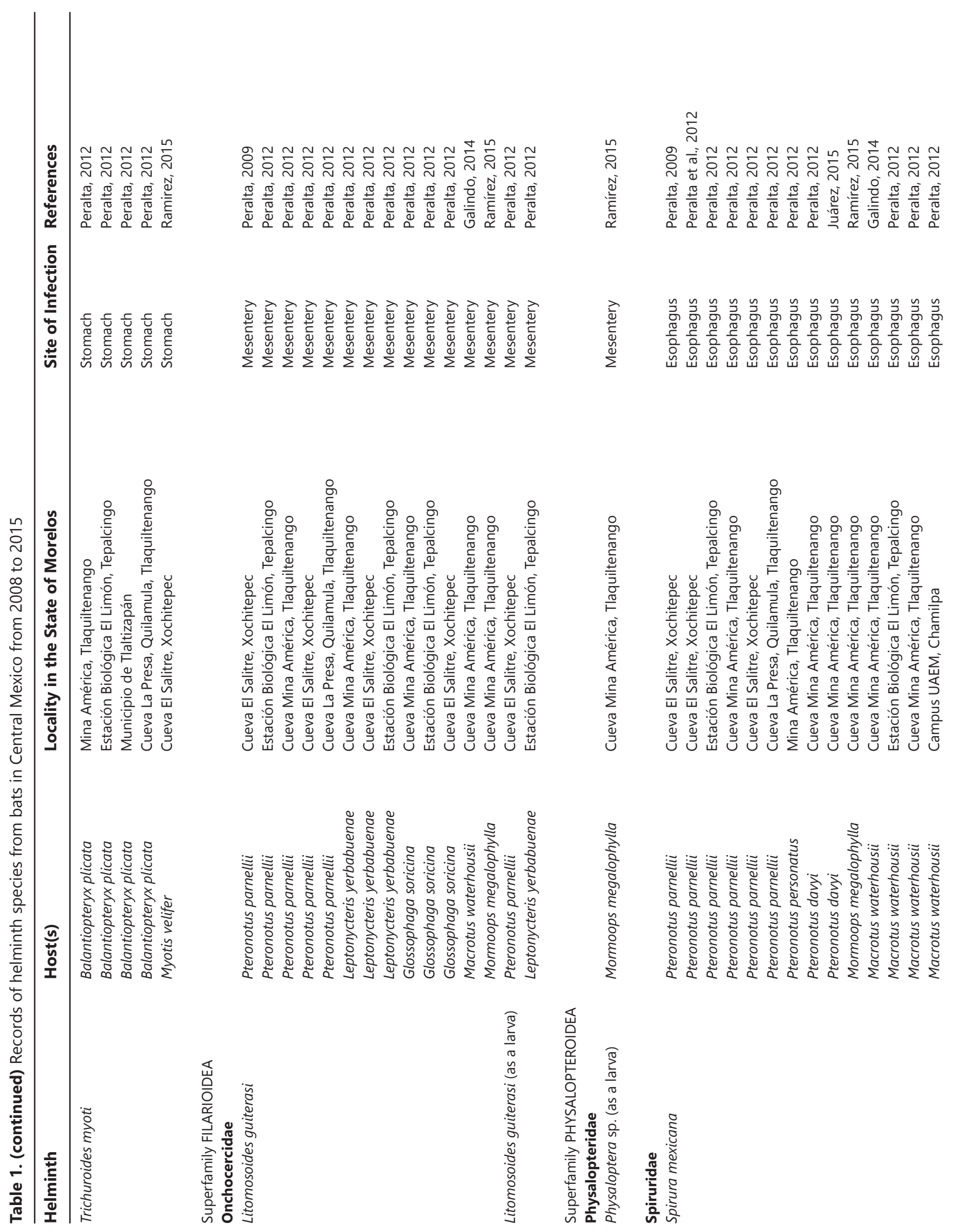




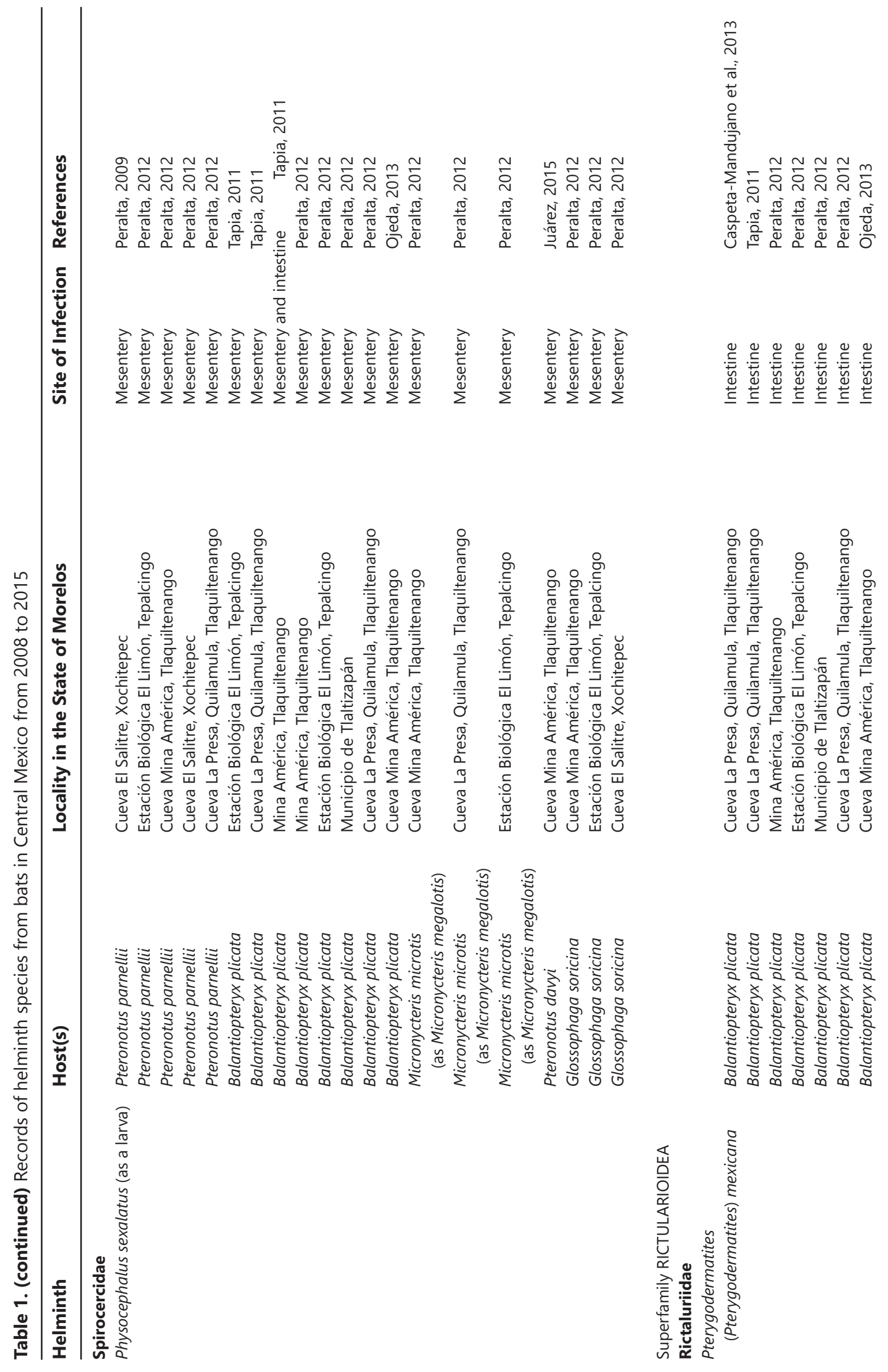




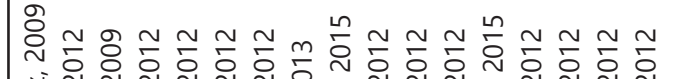

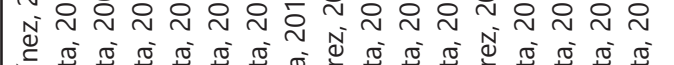

m

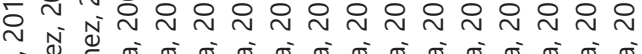

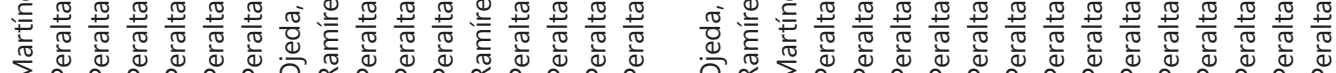

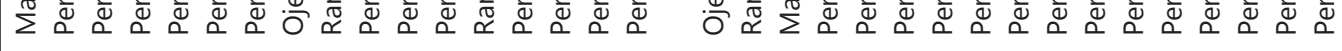

它

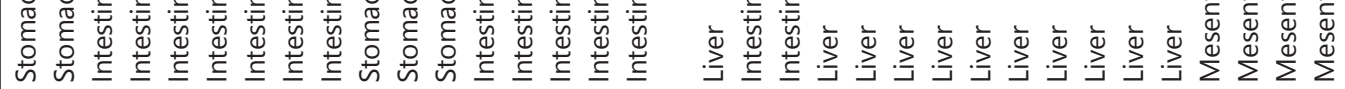

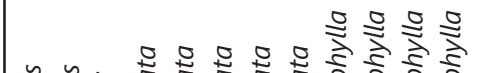

है

\& : ะ :

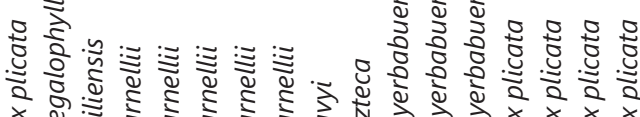

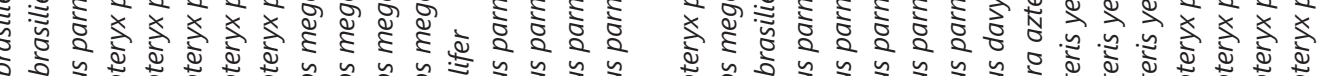

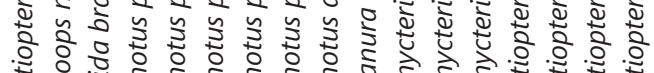

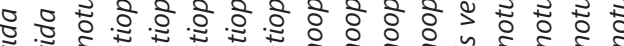

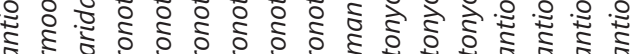

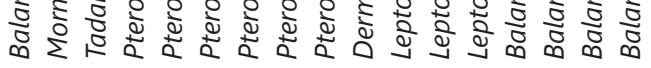


Voucher specimens of each helminth species were deposited in the Colección Nacional de Helmintos (CNHE), Instituto de Biología, Universidad Nacional Autónoma de México. Names for all bat species have been standardized using current nomenclature (Wilson and Reeder, 2005; Ceballos and Arroyo-Cabrales, 2012). However, information available in some published accounts did not allow this because in some cases there was no voucher specimen for the host and/or several congeneric species occur in sympatry, which makes identification impossible based on nonstandard common names. The taxonomy of helminths follows the criteria used in previous checklists of Neotropical bats (Santos and Gibson, 2015).

\section{Results}

\section{Composition of the helminthological record}

The helminthological record in bats in Mexico includes 59\% of taxa included in Nematoda and $41 \%$ of Platyhelminthes. The mayority of the species assigned to Platyhelminthes (85\%) belongs to the class Trematoda, whereas the remaining $15 \%$ belongs to Cestoda (Table 1).

\section{Helminth - bat records}

Table 2 offers a reconstruction of the host spectrum of each species of helminth. It is worth noting that several of the species of bats are known exclusively from one host and one locality, usually reported in their original description. This is the case for Rictularia nana Caballero, 1943; Bidigiticauda vivipara Chitwood, 1938; Pterygodermatites mexicana Caspeta-Mandujano et al., 2013; and Tricholeiperia pearsei Chitwood, 1938.

\section{Helminths recorded per species of bat}

The information presented in Table 3 acts as a helminthological record per each species of bat. From the 27 species of bats included, M. megalophylla shows the greatest number of records (23 taxa). The helminthological record for Trachops cirrhosus, Lasiurus cinereus, and L. blossevillii in Mexico includes a single species. In Table 4 we present those records that could not be confirmed given the lack of voucher specimens or a precise identification of the species of bat. Finally, in Table 5 we present a relationship of the bat-helminth association.

\section{Discussion}

The helminthological record for bats in Mexico includes 49 taxa, 68 including available records for Central America. This number is relatively low given a high expectation of species diversity resulting from the high diversity and abundance of bats in this megadiverse region. This apparent low diversity may be an artifact of sampling, since several of the species of parasites are known from a single record (Chandler, 1938; Chitwood, 1938; Stunakrd, 1938). In Mexico and Central America, there are very few studies that include a comprehensive survey of the helminthological fauna in a diverse group of bats, following a geographical or taxonomical approach (Ubelaker et al., 1979; Vaucher and Durette-Desset, 1986; Guzmán-Cornejo et al., 2003; Clarke, 2008). The value of surveys examining several species of bats in a single locality is threefold in that it increases the chances in detecting rare species of parasites, allows identifying patterns of host specificity (see Table 5), and facilitates the determination of a range of distribution for each species of parasite. The latter is an important aspect because species of parasites may feature a more restricted geographic distribution than their hosts.

Finally, our results highlight the relevance of methodic localized-intensive surveys to both characterize the host range of metazoan parasites and increase the chance of detecting rare or uncommon species. This information is crucial to assess the actual biodiversity of a region. With an area of $4,950 \mathrm{~km}^{2}$, Morelos is slightly larger than the state of Rhode Island $\left(3,672 \mathrm{~km}^{2}\right)$, yet the results of our parasitological examinations resulted in 34 species of helminths (Table 1). This number represents $58 \%$ of the species of helminths recorded in Mexico. In addition, the diversity of helminths in Morelos includes 4 species that were described by our team (Peralta-Rodríguez et al., 2012; Caspeta-Mandujano et al., 2013, 2015; Jiménez et al., 2014), which represents $8 \%$ of the diversity of helminths reported in chiropterans in Mexico. In comparison, the total number of bat species surveyed for helminths in Mexico includes 19 species, which roughly represents $14 \%$ of the total diversity of chiropterans present in this country. Using a simple linear relationship, one may expect that the helminthological examination of the remaining 121 species of bats will result in the description of at least 25 new species, yet this number must be greater assuming that there are species of bats which have never been surveyed for parasites, including members of the families Noctilionidae and Thyropteridae, which have very specialized diets and morphology.

Acknowledgments - This study was supported by a research grant from the Programa de Mejoramiento del Profesorado (PROMEP-UAEMOR/07/203) to J.M.C.M. and J.A.G. and by Programa Integral de Fortalecimiento Institucional (PIFI-UAEM 2010-2011), and by the Fondo de Consolidación PROMEP-UAEM, Cuerpo Académico Biología Comparada. J.L.P.R. was supported by a scholarship from CONACYT (241472). Thanks are extended to Luis García Prieto, collection manager of the Colección Nacional de Helmintos for facilitating the access to specimens and specialized literature. Special thanks to the working people of Morelos, for their logistic, moral, and financial support during the completion of these investigations. 


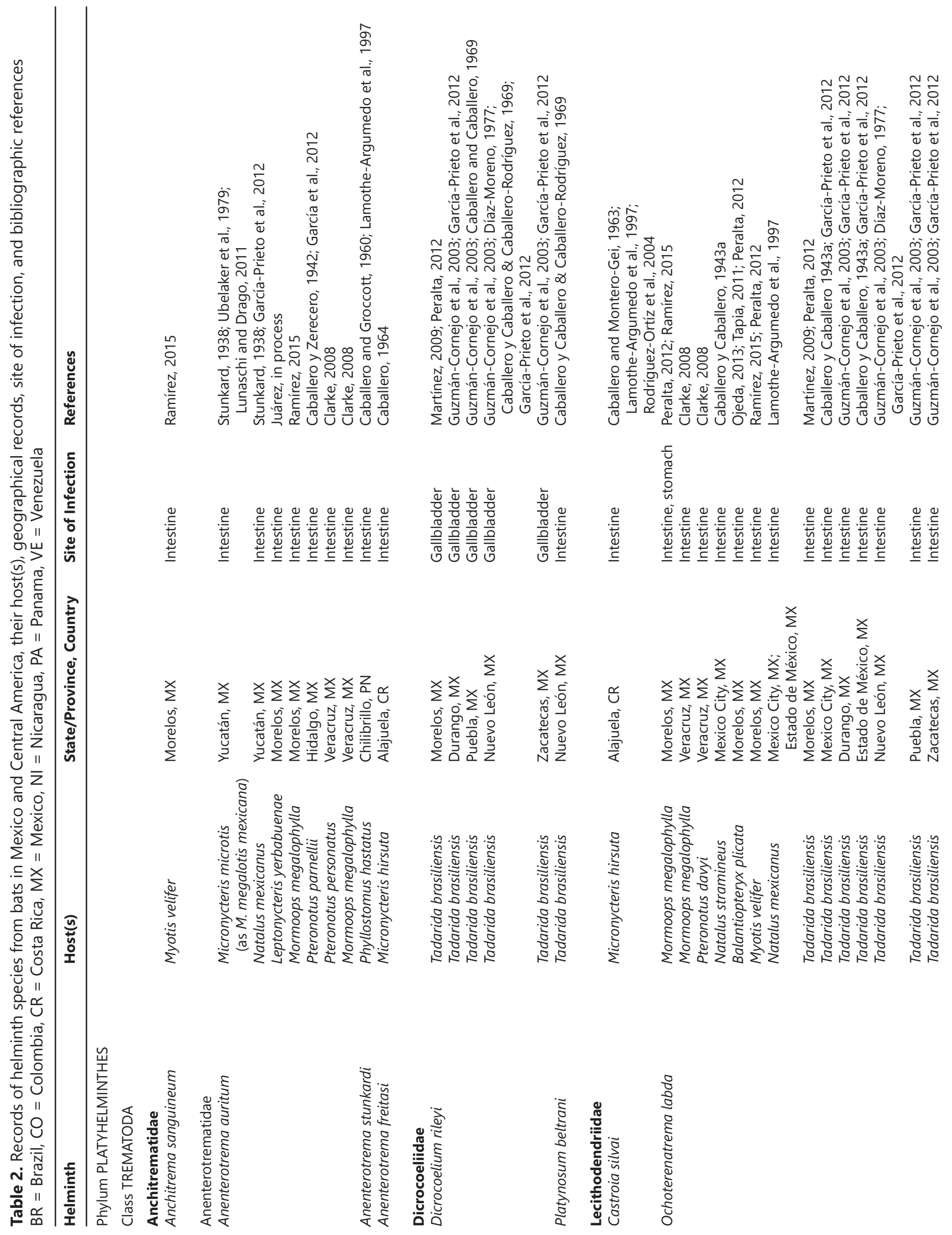




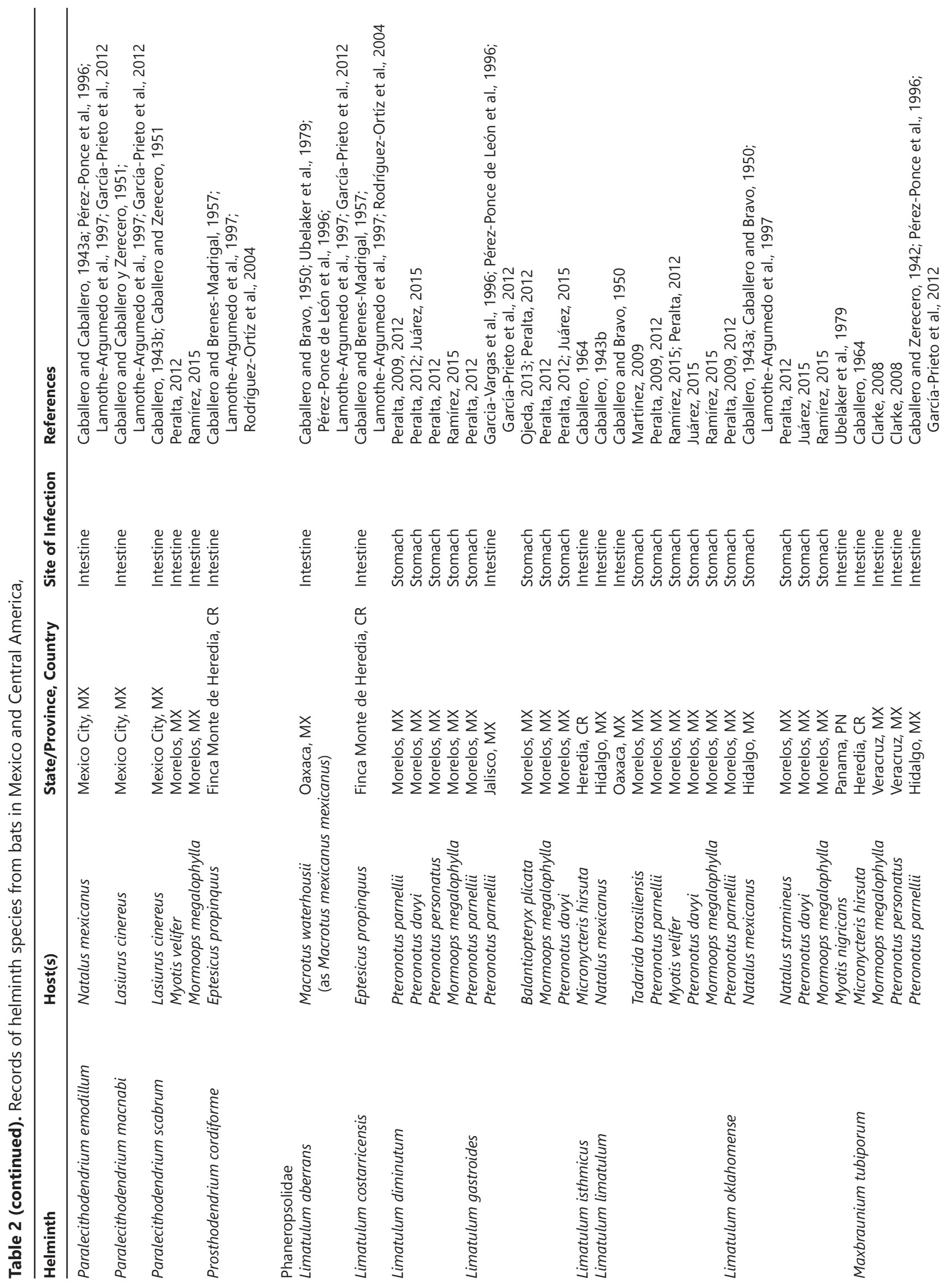




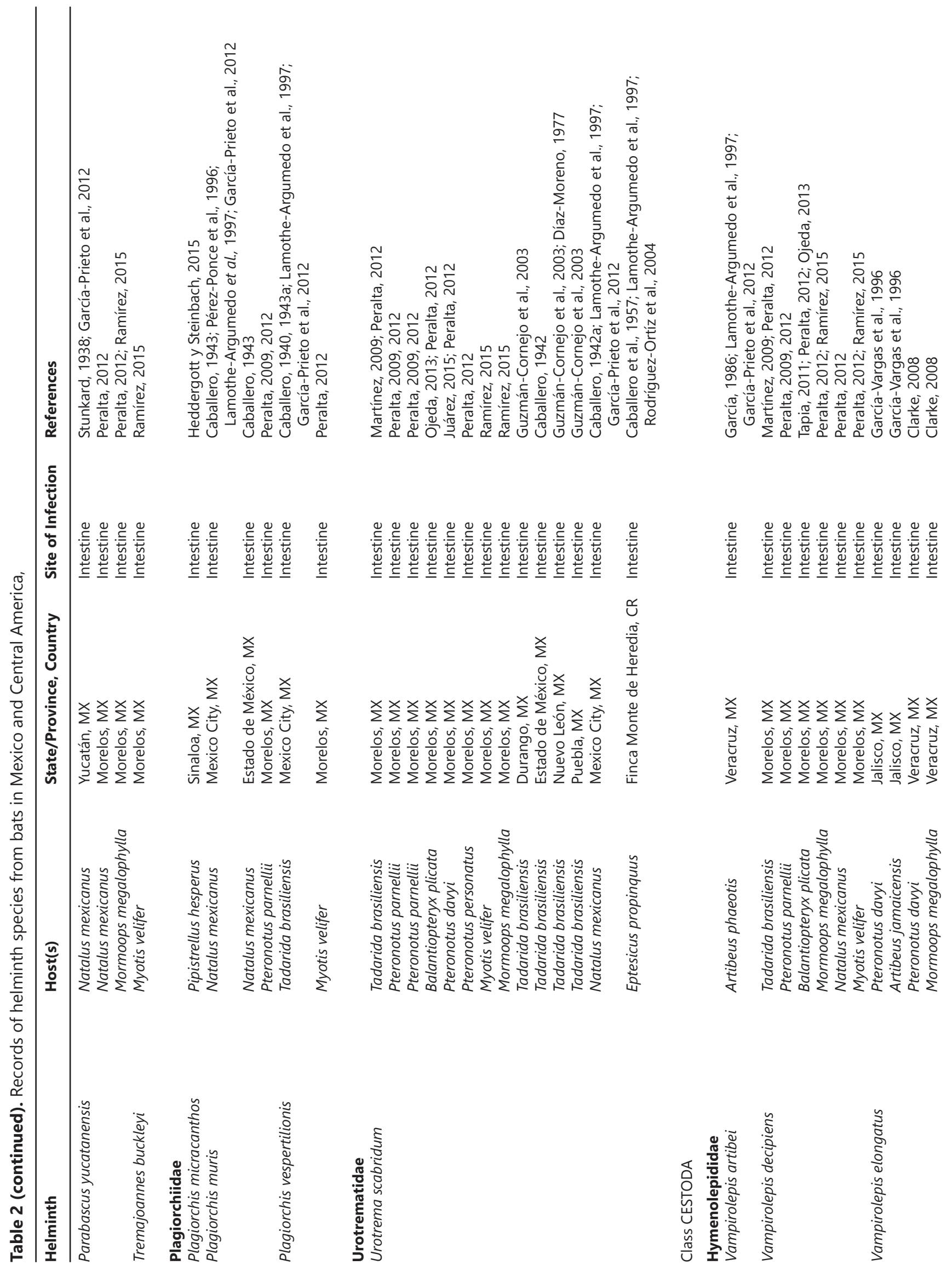




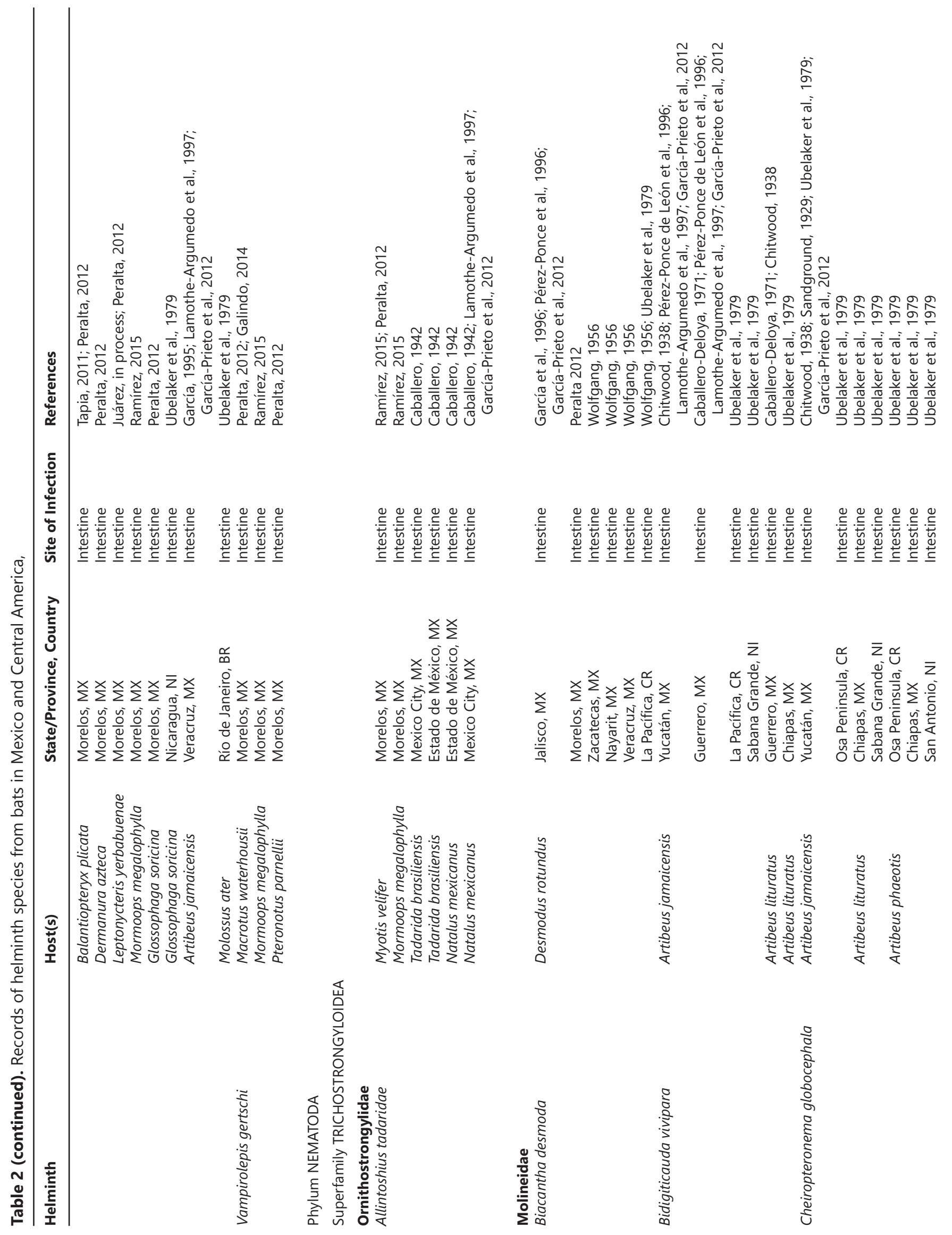




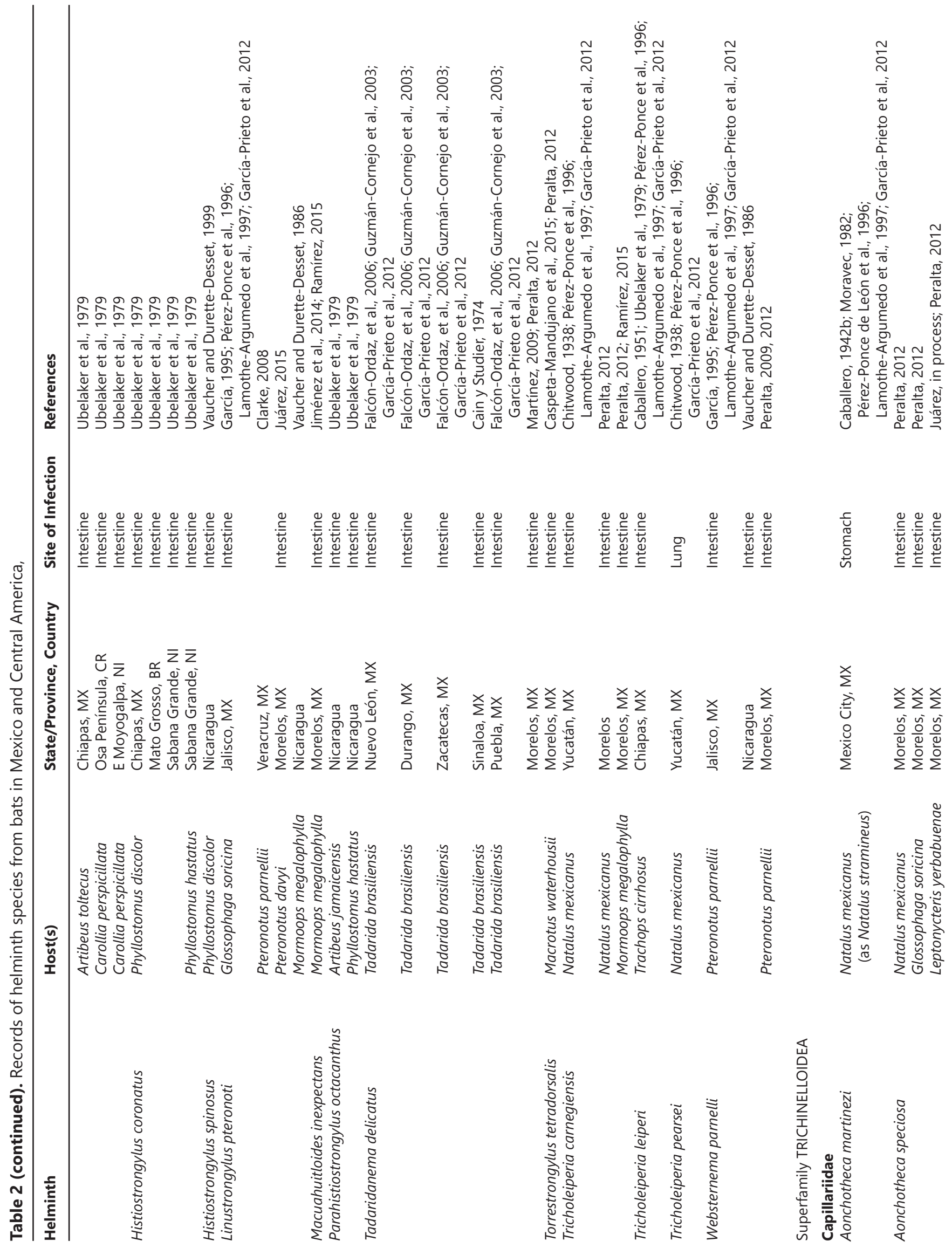




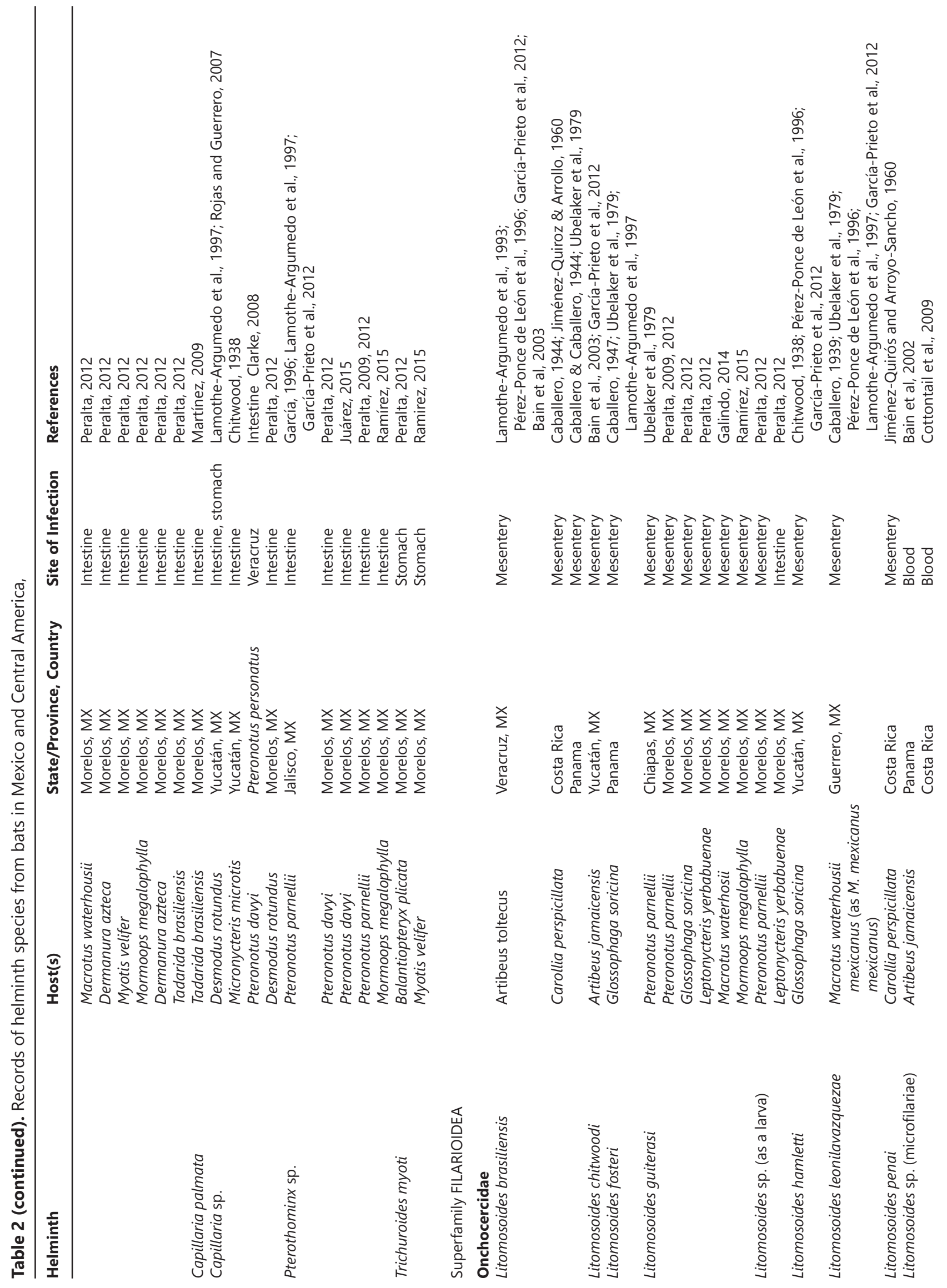




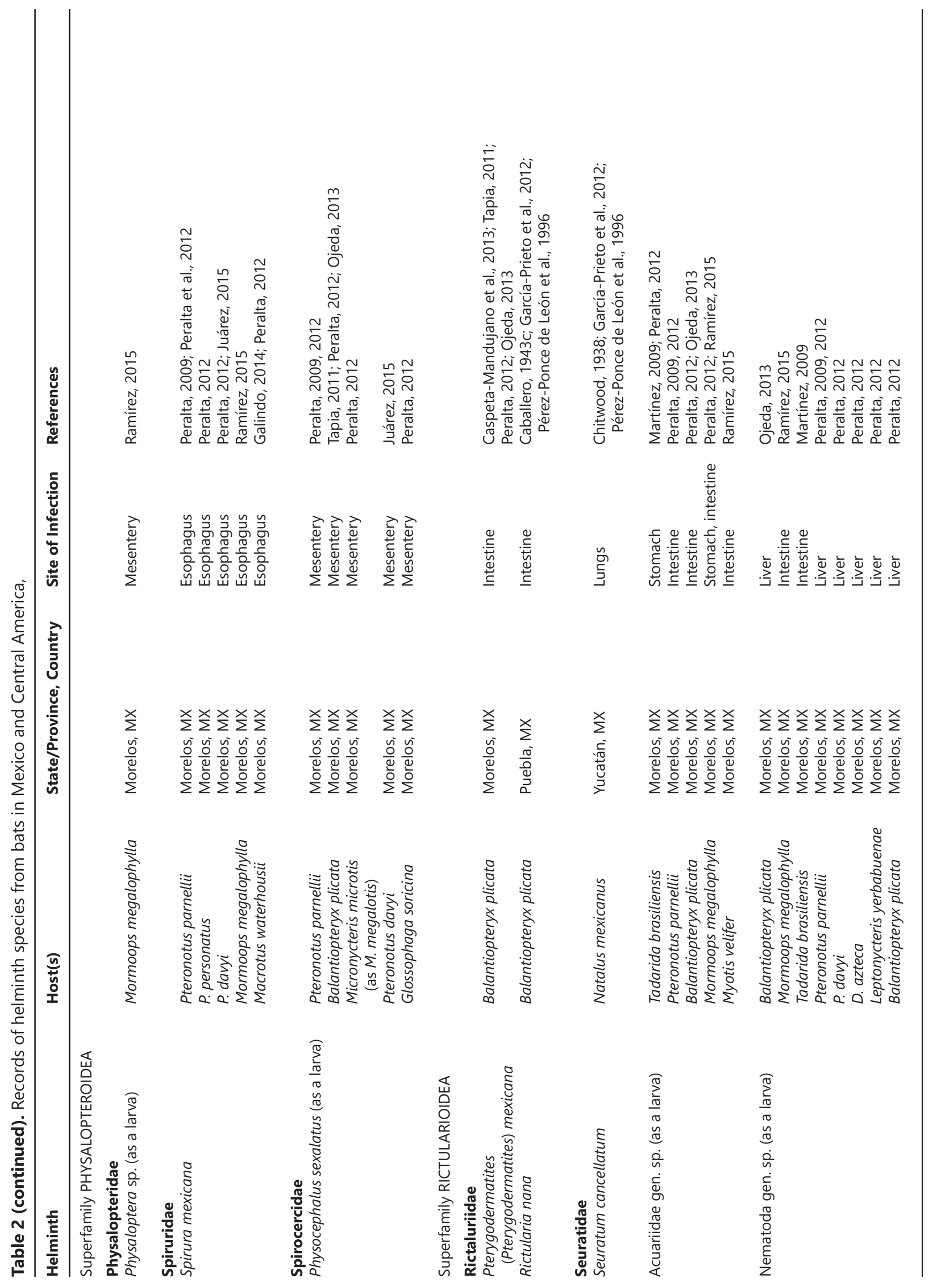


Table 3. Checklist of species of parasites recorded per bat species in Mexico and Central America

Bat Species Helminth Species References

Family Emballonuridae

Balantiopteryx plicata Peters, 1867

Family Molossidae

Tadarida brasiliensis (Geoffroy, 1824)

Family Mormoopidae

Mormoops megalophylla Peters, 1864

Ochoterenatrema labda
Limatulum gastroides
Urotrema scabridum
Vampirolepis decipiens
Vampirolepis elongatus
Trichuroides myoti
Physocephalus sexalatus (as a larva)
Pterygodermatites (Pterygodermatites) mexicana
Rictularia nana
Acuariidae gen. sp. (as a larva)
Nematoda gen. sp. (as a larva)

Dicrocoelium rileyi

Platynosum beltrani

Ochoterenatrema labda

Limatulum limatulum

Plagiorchis vespertilionis

Urotrema scabridum

Vampirolepis decipiens

Allintoshius tadaridae

Tadaridanema delicatus

Capillaria palmata

Acuariidae gen. sp. (as a larva)

Nematoda gen. sp. (as a larva)

Anenterotrema auritum
Ochoterenatrema labda
Paralecithodendrium scabrum
Limatulum diminutum
Limatulum gastroides
Limatulum limatulum
Limatulum oklahomense
Maxbraunium tubiporum
Parabascus yucatanensis
Urotrema scabridum
Vampirolepis decipiens
Vampirolepis elongatus
Vampirolepis gertschi
Allintoshius tadaridae
Aonchoteca speciose; Linustrongylus pteronoti
Macuahuitloides inexpectans
Tricholeiperia carnegiensis
Pterothominx sp.
Litomosoides guiterasi
Physaloptera sp.
Spirura mexicana
Acuariidae gen. sp. (as a larva)
Nematoda gen. sp. (as a larva)

\author{
Caballero, 1943 \\ García, 1995 \\ Caballero y Caballero 1942a \\ Peralta, 2009 \\ García, 1995 \\ Peralta, 2012 \\ Peralta, 2012 \\ Caspeta-Mandujano et al. 2013 \\ Caballero, 1943c \\ Peralta, 2012 \\ Peralta, 2012
}

Caballero and Caballero, 1969

Caballero and Caballero, 1969

Caballero, 1943

Caballero, 1943b

Caballero, 1940

Caballero, 1942

Peralta, 2012

Caballero, 1942

Falcon-Ordaz et al., 2006

Martínez, 2009

Martínez, 2009

Martínez, 2009

\author{
Ramírez, 2015 \\ Peralta, 2012 \\ Ramírez, 2015 \\ Ramírez, 2015 \\ Peralta, 2012 \\ Ramírez, 2015 \\ Ramírez, 2015 \\ Ramírez, 2015 \\ Peralta, 2012 \\ Ramírez, 2015 \\ Peralta, 2012 \\ Ramírez, 2015 \\ Peralta, 2012 \\ Ramírez, 2015 \\ Peralta, 2012; Ramírez, 2015 \\ Jiménez et al., 2013 \\ Ramírez, 2015 \\ Ramírez, 2015 \\ Ramírez, 2015 \\ Ramírez, 2015 \\ Peralta et al., 2012 \\ Peralta, 2012 \\ Ramírez, 2015
}


Table 3 (continued). Checklist of species of parasites recorded per bat species in Mexico and Central America

\begin{tabular}{|c|c|c|}
\hline Bat Species & Helminth Species & References \\
\hline \multirow[t]{12}{*}{ Pteronotus davyi Gray, 1838} & Ochoterenatrema labda & Clarke, 2008 \\
\hline & Limatulum diminutum & Peralta, 2012 \\
\hline & Limatulum gastroides & Peralta, 2012 \\
\hline & Limatulum limatulum & García, 1995 \\
\hline & Limatulum oklahomense & Peralta, 2012 \\
\hline & Urotrema scabridum & Peralta, 2012 \\
\hline & Vampirolepis elongatus & García, 1995 \\
\hline & Linustrongylus pteronoti & García, 1995 \\
\hline & Websternema parnelli & García, 1965 \\
\hline & Pterothominx sp. & García, 1995 \\
\hline & Litomosoides guiterasi (as a larva) & Peralta, 2012 \\
\hline & $\begin{array}{l}\text { Physocephalus sexalatus (as a larva); } \\
\text { Nematoda gen. sp. (as a larva) }\end{array}$ & Juárez, 2015; Peralta, 2012 \\
\hline \multirow[t]{16}{*}{ Pteronotus parnellii Miller, 1902} & Limatulum diminutum & Peralta, 2009 \\
\hline & Limatulum gastroides & García, 1995 \\
\hline & Limatulum limatulum & Peralta, 2009 \\
\hline & Limatulum oklahomense & Peralta, 2009 \\
\hline & Plagiorchis muris & Peralta, 2009 \\
\hline & Urotrema scabridum & Peralta, 2009 \\
\hline & Vampirolepis decipiens & Peralta, 2009 \\
\hline & Vampirolepis gertschi & Peralta, 2012 \\
\hline & Linustrongylus pteronoti & Peralta, 2009 \\
\hline & Websternema parnelli & Garcia, 1995 \\
\hline & Pterothominx sp. & Peralta, 2009 \\
\hline & Litomosoides guiterasi & Peralta, 2009 \\
\hline & Litomosoides guiterasi (as a larva) & Peralta, 2009 \\
\hline & Spirura mexicana & Peralta, 2009 \\
\hline & Physocephalus sexalatus (as a larva) & Peralta, 2009 \\
\hline & Acuariidae gen. sp. (as a larva) & Peralta, 2009 \\
\hline \multirow[t]{4}{*}{ Pteronotus personatus (Wagner, 1843) } & Limatulum diminutum & Peralta, 2012 \\
\hline & Limatulum gastroides & Peralta, 2012 \\
\hline & Maxbraunium tubiporum & Peralta, 2012 \\
\hline & Urotrema scabridum & Peralta, 2012 \\
\hline \multicolumn{3}{|l|}{ Family Natalidae } \\
\hline \multirow[t]{14}{*}{ Natalus mexicanus Miller, 1902} & Anenterotrema auritum & Stunkard, 1938 \\
\hline & Ochoterenatrema labda & Lunaschi and Drago, 2011 \\
\hline & Paralecithodendrium emodillum & Caballero, 1943b \\
\hline & Limatulum limatulum & Caballero, 1943b \\
\hline & Limatulum oklahomense & Caballero and Bravo Hollis, 1950 \\
\hline & Parabascus yucatanensis & Stunkard, 1938 \\
\hline & Plagiorchis muris & Caballero, 1943 \\
\hline & Urotrema scabridum & Caballero, 1942 \\
\hline & Vampirolepis decipiens & Peralta, 2012 \\
\hline & Allintoshius tadaridae & Caballero, 1942 \\
\hline & Tricholeiperia carnegiensis & Chitwood, 1938 \\
\hline & Tricholeiperia pearsei & Chitwood, 1938 \\
\hline & Aonchotheca speciosa & \\
\hline & Seuratum cancellatum & Chitwood, 1938 \\
\hline
\end{tabular}


Table 3 (continued). Checklist of species of parasites recorded per bat species in Mexico and Central America

\begin{tabular}{|c|c|c|}
\hline Bat Species & Helminth Species & References \\
\hline \multicolumn{3}{|l|}{ Family Phyllostomidae } \\
\hline \multirow[t]{3}{*}{ Artibeus aztecus (Andersen, 1906) } & Vampirolepis elongatus & Peralta, 2012 \\
\hline & Aonchotheca speciosa & Peralta, 2012 \\
\hline & Litomosoides guiterasi (as a larva) & Peralta, 2012 \\
\hline \multirow[t]{2}{*}{ Artibeus phaeotis (Miller, 1902) } & Vampirolepis artibei & García, 1986 \\
\hline & Cheiropteronema globocephala & Chitwood 1938 \\
\hline \multirow[t]{6}{*}{ Artibeus jamaicensis Leach, 1821} & Vampirolepis elongatus & García, 1995 \\
\hline & Bidigiticauda vivipara & Chitwood 1938 \\
\hline & Cheiropteronema globocephala & Chitwood, 1938 \\
\hline & Parahistiostrongylus octacanthus & Ubelaker et al., 1979 \\
\hline & Litomosoides chitwoodi & Bain et al., 2003 \\
\hline & Litomosoides sp. & García, 1995 \\
\hline \multirow[t]{2}{*}{ Artibeus lituratus (Olfers, 1928) } & Bidigiticauda vivipara & Caballero-Deloya 1971 \\
\hline & Cheiropteronema globocephala & Ubelaker et al., 1979 \\
\hline \multirow[t]{2}{*}{ Artibeus toltecus (Saussure, 1860) } & Cheiropteronema globocephala & Ubelaker et al., 1979 \\
\hline & Litomosoides brasiliensis & Bain et al, 2003 \\
\hline \multirow[t]{3}{*}{ Carollia perspicillata (L. 1758) } & Cheiropteronema globocephala & Ubelaker et al., 1979 \\
\hline & Litomosoides brasiliensis & Bain et al, 2003 \\
\hline & Litomosoides penai & $\begin{array}{l}\text { Jiménez-Quirós and Arroyo-Sancho, } \\
1960\end{array}$ \\
\hline \multirow[t]{2}{*}{ Desmodus rotundus Geoffroy, 1810} & Biacantha desmoda & García, 1995 \\
\hline & Capillaria sp. & Peralta, 2012 \\
\hline \multirow[t]{2}{*}{ Glossophaga soricina Pallas, 1766} & Anenterotrema auritum & Lunaschi and Drago, 2011 \\
\hline & Litomosoides hamletti; Vampirolepis elongatus & Chitwood, 1938; Ubelaker et al., 1979 \\
\hline \multirow{6}{*}{$\begin{array}{l}\text { Leptonycteris yerbabuenae } \\
\text { Martínez and Villa, } 1940\end{array}$} & Anenterotrema auritum & Juárez-González, pers. comm. \\
\hline & & \\
\hline & Vampirolepis elongatus & Peralta, 2012 \\
\hline & Aonchotheca speciosa & Juárez-González, pers. comm. \\
\hline & Litomosoides guiterasi & Peralta, 2012 \\
\hline & Litomosoides guiterasi (as a larva) & Peralta, 2012 \\
\hline \multirow[t]{7}{*}{ Macrotus waterhousii Gray, 1843} & Limatulum aberrans & Caballero and Bravo, 1950 \\
\hline & Litomosoides leonilavazquezae & Caballero, 1939 \\
\hline & Vampirolepis gertschi & Galindo, 2014; Ramírez, 2015 \\
\hline & Torrestrongylus tetradorsalis & Caspeta-Mandujano et al., 2015 \\
\hline & Aonchotheca speciosa & Peralta, 2012 \\
\hline & Spirura mexicana & Peralta et al., 2012 \\
\hline & Litomosoides guiterasi & Galindo, 2014 \\
\hline \multirow[t]{4}{*}{ Micronycteris hirsuta } & Anenterotrema freitasi & Caballero, 1964 \\
\hline & Limatulum isthmicus & Caballero, 1964 \\
\hline & Castroia silvai & Caballero and Montero-Gei, 1963 \\
\hline & Maxbraunium tubiporum & Caballero, 1964 \\
\hline \multirow[t]{2}{*}{ Micronycteris microtis } & Anenterotrema auritum & Stunkard, 1938 \\
\hline & Capillaria sp. & Chitwood, 1938 \\
\hline \multirow[t]{2}{*}{ Phyllostomus discolor (Wagner, 1843) } & Histiostrongylus coronatus & Ubelaker et al., 1979 \\
\hline & Histiostrongylus spinosus & Vaucher and Durette-Desset, 1999 \\
\hline \multirow[t]{3}{*}{ Phyllostomus hastatus (Pallas, 1767) } & Anenterotrema stunkardi & Caballero and Groccott, 1960 \\
\hline & Histiostrongylus coronatus & Ubelaker et al., 1979 \\
\hline & Parahistiostrongylus octacanthus & Ubelaker et al., 1979 \\
\hline Trachops cirrhosus Spix, 1823 & Tricholeiperia leiperi & Chitwood, 1938 \\
\hline
\end{tabular}


Table 3 (continued). Checklist of species of parasites recorded per bat species in Mexico and Central America

\begin{tabular}{lll}
\hline Bat Species & Helminth Species & References \\
\hline Family Vespertilionidae & & Caballero and Cerecero, 1942 \\
Lasiurus blossevillii (as Vespertilio lasiurus) & Maxbraunium tubiporum & Caballero and Zerecero, 1951 \\
Lasiurus cinereus Beauvois, 1796 & Paralecithodendrium macnabi & Galindo, 2014; Ramírez, 2015 \\
& Paralecithodendrium scabrum & Caballero and Brenes-Madrigal, 1957 \\
Eptesicus sp. & Prosthodendrium cordiforme & Caballero and Brenes-Madrigal, 1957 \\
& Limatulum costarricensis & Caballero et al., 1957 \\
Myotis velifer Allen, 1890 & Urotrema scabridum & Ramírez, 2015 \\
& Anchitrema sanguineum & Ramírez, 2015 \\
& Ochoterenatrema labda & Ramírez, 2015 \\
& Paralecithodendrium scabrum & Ramírez, 2015 \\
& Limatulum limatulum & Ramírez, 2015 \\
& Tremajoannes buckleyi & Ramírez, 2015 \\
& Plagiorchis vespertilionis & Ramírez, 2015 \\
& Urotrema scabridum & Ramírez, 2015 \\
& Vampirolepis decipiens & Ramírez, 2015 \\
& Allintoshius tadaridae & Ramírez, 2015 \\
& Trichuroides myoti & Ramírez, 2015
\end{tabular}

Table 4. Records in Mexico listing species of helminths with no confirmed host identification and not considered in this checklist

\begin{tabular}{lllll}
\hline Helminth & Host & State & Site of Infection & References \\
\hline Nematoda & & & & \\
& & & & Espericueta, 2012 \\
Capillaridae & None provided & Sinaloa & - & Espericueta, 2012 \\
Rhabditida (?) & None provided & Sinaloa & García-Márquez, 1985 \\
Biacantha sp. & Desmodus rotundus & Colima & Intestine & Chitwood, 1938 \\
Capillaria sp. & Micronycteris megalotis mexicana & Yucatán & Stomach & García, 1995 \\
Litomosoides sp. & Artibeus jamaicensis, A. intermedius & Jalisco & Mesentery & García, 1995 \\
Pterothomix sp. & Pteronotus davyi & Jalisco & Intestine & Guzmán-Cornejo et al., 2003 \\
Vampirolepis sp. & Tadarida brasiliensis & Nuevo León, Puebla, Zacatecas & Intestine & Eslava, 2005 \\
Vexillata sp. & Artibeus jamaicensis & Morelos & Intestine & \\
\hline
\end{tabular}


Table 5. Distribution of parasites in the bat species surveyed for helminthes up to 2015

Species of parasite

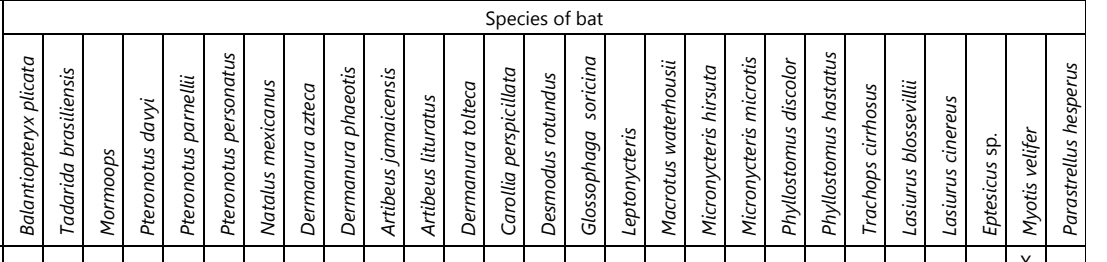

Anchitrema sanguineum

Anenterotrema auritum

Anenterotrema freitasi

Anenterotrema stunkardi

Dicrocoelium rileyi

Platynosum beltrani

Castroia silvai

Ochoterenatrema labda

Paralecithodendrium emodillum

Paralecithodendrium macnabi

Paralecithodendrium scabrum

Prosthodendrium cordiforme

Limatulum aberrans

Limatulum costarricensis

Limatulum diminutum

Limatulum gastroides

Limatulum isthmicus

Limatulum limatulum

Limatulum oklahomense

Maxbraunium tubiporum

Parabascus yucatanensis

Tremajoannes buckleyi

Plagiorchis micracanthos

Plagiorchis muris

Plagiorchis vespertilionis

Urotrema scabridum

Vampirolepis artibei

Vampirolepis decipiens

Vampirolepis elongatus

Vampirolepis gertschi

Allintoshius tadaridae

Biacantha desmoda

Bidigiticauda vivipara

Cheiropteronema globocephala

Histiostrongylus coronatus

Histiostrongylus spinosus

Linustrongylus pteronoti

Macuahuitloides inexpectans

Parahistiostrongylus octacanthus

Tadaridanema delicatus

Torrestrongylus tetradorsalis

Tricholeiperia carnegiensis

Tricholeiperia leiperi

Tricholeiperia pearsei

Websternema parnelli

Aonchotheca martinezi

Aonchotheca speciosa

Capillaria palmata

Capillaria sp.

Pterothominx sp.

Trichuroides myoti

Litomosoides brasiliensis

Litomosoides chitwoodi

Litomosoides fosteri

Litomosoides guiterasi

Litomosoides hamletti

Litomosoides leonilavazquezae

Litomosoides penai

Litomosoides $s p$.

Physaloptera sp. (as a larva)

Spirura mexicana

Spirocercidae

Physocephalus sexalatus (as a larva)

Pterygodermatites (Pterygodermatites) mexicana

Rictularia nana

Seuratum cancellatum

Acuariidae gen. sp. (as a larva)

Nematoda gen. sp. (as a larva)

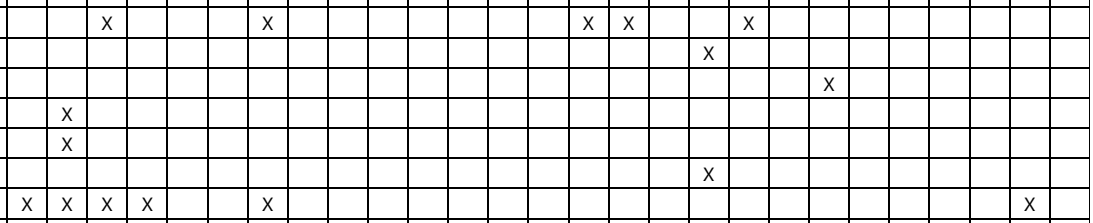

\begin{tabular}{|l|l|l|l|l|l|l|l|}
$\mathrm{X}$ & $\mathrm{X}$ & $\mathrm{x}$ & $\mathrm{x}$ & & & $\mathrm{x}$ & \\
\hline & & & & & & $\mathrm{x}$ & \\
\hline
\end{tabular}

+




\section{Literature Cited}

Bain, O.; Babayan, S.; Gomes, J.; Rojas, G.; and Guerrero, R. 2002. First account on the larval biology of a Litomosoides filaria from a bat. Parassitologia (Rome) 44: 89-92. doi: 10.1016/j. exppara.2015.06.007

Bain, O.; Guerrero, R.; Rodriguez, B.; Babayan, S.; and Jouvenet, N. 2003. Examination of type material of two species of Litomosoides (Filarioidea : Onchocercidae) parasites from bats; Taxonomic consequences. Parasite 10: 211-218. doi: 10.1051/parasite/2003103211

Caballero, C.E. 1939. A new filarid from Mexican bats. Transactions of the American Microscopical Society 58: 156-458.

Caballero, C. E. 1940. Algunos tremátodos intestinales de los murciélagos de México. Universidad Nacional Autónoma de México, Anales del Instituto de Biología 11: 215-223.

Caballero, C.E. 1942a. Tremátodos de los murciélagos de México III. Descripción de Urotrema scabridum Braun, 1900 y posición sistemática de las especies norteamericanas de este género. Universidad Nacional Autónoma de México, Anales del Instituto de Biología 13: 641-648.

Caballero, C. E. 1942b. Descripción de la segunda especie de Capillaria encontrada en los murciélagos del Norte. III. Universidad Nacional Autónoma de México, Anales del Instituto de Biología 13: 649-654.

Caballero, C. E. 1943a. Tremátodos de los murciélagos de México IV. Descripción de un nuevo género de la subfamilia Lecithodendriidae Loss, 1902, y una nueva especie de Prosthodendrium Dollfus, 1931. Universidad Nacional Autónoma de México, Anales del Instituto de Biología 14: 173-192.

Caballero, C. E. 1943b. Algunas especies de tremátodos de los murciélagos de la región de Izucar de Matamoros, Puebla. Universidad Nacional Autónoma de México, Anales del Instituto de Biología 14: 423-430.

Caballero, C. E. 1943c. Nemátodos de los murciélagos de México IV. Descripción de una nueva especie del género Rictularia y breves consideraciones sobre la sistemática de las especies de Biología. Universidad Nacional Autónoma de México, Anales del Instituto de Biología 14: 431-438.

Caballero, C. E. 1947. Algunas filarias de mamíferosy de reptiles de las Repúblicas de Colombia y Panamá. Universidad Nacional Autónoma de México, Anales del Instituto de Biología 18: 169-188.

Caballero, C. E. 1951. Estudios helmintológicos de la región oncocercosa de México y de la República de Guatemala. Nematoda. 6a parte. Y algunas consideraciones en torno a los géneros Onchocerca Diesing, 1841, y Acanthospiculum Skrjabin y Schikobalova, 1948. Universidad Nacional Autónoma de México, Anales del Instituto de Biología 22: 141-158.

Caballero, C. E. 1964. Tres nuevas especies de Trematoda Rudolphi, 1808 que parasitan a murciélagos (Chiroptera Blumembach, 1774) de América Latina. Cuadernos del Instituto de Investigaciones Científical de la Universidad Nacional Autónoma de Nuevo León 5: 1-34.
Caballero, C. E.; and Bravo, M. 1950. Tremátodos de los murciélagos de México VI. Descripción de una nueva especies de Limatulum (Trematoda: Lecithodendriidea). Universidad Nacional Autónoma de México, Anales del Instituto de Biología, Serie Zoología 21: 345-350.

Caballero, C. E.; and Brenes-Madrigal, R. 1957. Helmintos de la República de Costa Rica VI. Algunos tremátodos de peces, reptiles y mamíferos. Anales del Instituto de Biología de la Universidad Nacional Autónoma de México 28: 217-240.

Caballero, C. E.; Brenes-Madrigal, R.; and Jiménez-Quirós, O. 1957. Helmintos de la República de Costa Rica IV. Algunos tremátodos de animales domésticos y silvestres. Revista de Biolgía Tropical 5: 135-155. doi: 10.15517/rbt. v64i4.21553

Caballero, C. E.; and Caballero-Rodríguez, G. 1969. Tremátodos de los murciélagos de México. IX. Descripción de una nueva especie de Platynosomum Looss, 1907 y a continuación el primer suplemento del catálogo taxonómico de los tremátodos que parasitan a los murciélagos. Revista de la Sociedad Mexicana de Historia Natural 30: 263-290.

Caballero, C. E.; and Groccott, R. G. 1960. Helmintos de la República de Panama. 23. Estudis de los trematodos de murciélagos, con descripcion de una nueva especie. Ciencia (Mexico) 19: 244-248.

Caballero, C. E.; and Montero-Gei, F. 1963. Presencia de Castroia silvai Travassos, 1928, (Trematoda, Digenea) en un murciélago de Costa Rica. Anales de la Escuela Nacional de Ciencias Biológicas 12: 85-89.

Caballero, C. E.; and Zerecero, C. 1942. Tremátodos de los murciélagos de México II. Redescripción y posición sistemática de Distomum tubiporum Braun, 1900. Universidad Nacional Autónoma de México, Anales del instituto de Biología, Serie Zoología 13: 97-104.

Caballero, C. E.; and Zerecero, C. 1951. Tremátodos de los murciélagos de México VII. Presencia de Paralecithodendrium macnabi Macy, 1936, en Lasiurus cinereus (Beauvois). Universidad Nacional Autónoma de México, Anales del Instituto de Biología 22: 159-167.

Caballero-Deloya, J. 1971. Redescripción de Bidigiticauda vivipara Chitwood, 1938 (Nematoda: Trichostrongylidae). Anales del Instituto de Biología, Universidad Nacional Autónoma de México 42: 33-40.

Caspeta-Mandujano, J. M.; Jiménez, F. A.; Peralta-Rodríguez, J. L.; and Guerrero, J. A. 2013. Pterygodermatites (Pterygodermatites) mexicana n. sp. (Nematoda: Rictulariidae), a parasite of Balantiopteryx plicata (Chiroptera) in Mexico. Parasite 20: 47. doi: 10.1051/parasite/2013047

Caspeta-Mandujano, J. M.; Peralta-Rodríguez, J. L.; GalindoGarcía, M.G.; and Jiménez, A. 2015. A new species of Torrestrongylus (Trichostrongylidae, Anoplostrongylinae) from Macrotus waterhousii (Chiroptera: Phyllostomidae) in Central Mexico. Parasite 22: 29. doi: 10.1051/parasite/2015029

Ceballos, G.; and Arroyo-Cabrales, J. Lista actualizada de los mamíferos de México 2012. Revista Mexicana de Mastozoología Nueva Época 2: 27-80. 
Chandler, A. C. 1938. A report on the parasites of a bat, Nycticeius humeralis, with descriptions of four new helminths. In Livro Jubilar do Professor Lauro Travassos, Instituto Oswaldo Cruz, Rio de Janeiro, Brazil, 107-114.

Chitwood, B. G. 1938. Some nematodes from the caves of Yucatan. In Fauna of the caves of Yucatan, A. S. Pearse (ed.). Carnegie Institution of Washington, Washington, D.C. 491: 51-66.

Clarke, C. E. 2008. "Descripción de la helmintofauna asociada a tres especies de murciélagos (Chiroptera: Mormoopidae) en el municipio de Apazapan, Veracruz." Tesis de Maestría, Instituto de Ecología, A. C., Xalapa, Veracruz México, 87 p.

Cottontail, V. M.; Wellinghausen, N.; and Kalko, E. K. V. 2009. Habitat fragmentation and haemoparasites in the common fruit bat, Artibeus jamaicensis (Phyllostomidae), in a tropical lowland forest in Panama. Parasitology 136: 1133-1145.

Díaz, M. R. 1977. Tremátodos digéneos del murciélago guanero Tadarida brasiliensis mexicana de la Cueva de San Bartolo, Santa Catarina, Nuevo León, México. B.S. Thesis, Facultad de Ciencias Biológicas, Universidad Autónoma de Nuevo León, Monterrey, Nuevo León, Mexico, 33 pp.

Eslava, A.G. 2005. Helmintos en la mastofauna silvestre de Monte Negro, Morelos, México. Tesis de Licenciatura. Facultad de Ciencias Biológicas. Universidad Autónoma del Estado de Morelos, 75 p.

Falcón-Ordaz, J.; Guzmán-Cornejo, C.; Garcia-Prieto, L.; and Lyell, G. 2006. Tadaridanema delicatus (Schwartz, 1927) n. gen., n. comb. (Trichostrongylina: Molienidae) parasite of molossidae bats. Journal of Parasitology 95: 1035-1042. doi: 10.1645/GE-744R.1

Fernández, J. A.; Hafner, M. S.; Hafner, D. J.; and F. A. Cervantes. 2014. Conservation status of rodents of the families Geomyidae and Heteromyidae of Mexico. Revista Mexicana de Biodiversidad 85: 576-588. doi: 10.7550/rmb.36710

Galindo, G. M. 2014. Helmintos Parásitos de Macrotus waterhousii Gray, 1843 (Chiroptera: Phyllostomidae) en la Reserva de la Biosfera Sierra de Huautla, Mina América, Tlaquiltenango, Morelos. Tesis de Licenciatura, Universidad Autónoma del Estado de Morelos. México, 75 p.

García P. L. 1986. Estudio taxonómico de algunos cestodos de vertebrados de México. Tesis de Licenciatura. Universidad Nacional Autónoma de México, México, D.F. 75 p.

García, V. F. 1995. Helmintos parásitos de murciélagos en la Estación de Biología, Chamela, Jalisco. Tesis de Licenciatura. Universidad Nacional Autónoma de México, México, D.F. 66 p.

García-Prieto, L.; Falcón-Ordaz, J.; and Guzmán-Cornejo, C. 2012. Helminth parasites of wild Mexican mammals: list of species, hosts and geographical distribution. Zootaxa 3290: 1-92.

García-Prieto, L.; Osorio-Sarabia, D.; and Lamothe-Argumedo, M. R. 2014. Biodiversidad de Nematoda parásitos de vertebrados en México. Revista Mexicana de Biodiversidad 85: S171-S176. doi: 10.7550/rmb.31746
Gardner, S. L.; and Jiménez-Ruiz, F. A. 2009. Methods for the study of bats endoparasites. In Ecological and Behavioral Methods for the Study of Bats, T. H. Kunz, S. Parsons (eds.). The Johns Hopkins University Press, Baltimore, MD. 795$805 \mathrm{p}$.

Guzmán-Cornejo, C.; Garciá-Prieto, L.; Acosta-Gutiérrez, R.; Falcón-Ordaz, J.; and León-Paniagua, L. 2012. Metazoarios parásitos de Tlacuatzin canescens y Marmosa mexicana (Mammalia: Didelphiomorphia) de México. Revista Mexicana de Biodiversidad 83: 557-561.

Guzmán-Cornejo, C.; García-Prieto, L.; Pérez-Ponce de León, G.; and Morales-Malacara, J. B. 2003. Parasites of Tadarida brasiliensis mexicana (Chiroptera: Molossidae) from arid regions of Mexico. Comparative Parasitology 70: 11-25. doi: 10.1654/1525-2647(2003)070[0011:POTBMC]2.0.CO;2

Hayman, D. T. S.; Bowen, R. A.; Cryan, P. M.; McCracken, G. F.; O'Shea, T. J.; Peel, A. J.; Gilbert, A.; Webb, C. T.; and Wood, J. L. N. 2013. Ecology of zoonotic infectious diseases in bats: current knowledge and future directions. Zoonoses and Public Health 60: 2-21. doi: 10.1111/zph.1200

Heddergott, M.; and Steinbach, R. 2015. Three new host species of Plagiorchis micracanthos (Macy, 1931) (Trematoda: Plagorchiidae) among North American bats (Chiroptera: Vespertillionidae). Helminthologia 52: 155-158. doi: $10.1515 /$ helmin-2015-0028

Jiménez, F. A. 2012. A new species of Carolinensis (Nematoda: Heligmonellidae) from Sumichrast's vesper rat Nyctomys sumichrasti. Comparative Parasitology 79: 208-213. doi: 10.1654/4569.1

Jiménez, F. A.; Peralta-Rodríguez, J. L.; Caspeta-Mandujano, J.; and Ramírez-Díaz, S. E. 2014. Macuahuitloides inexpectans n. gen., n. sp., (Molineidae: Anoplostrongylinae) from Mormoops megalophylla (Chiroptera: Mormoopidae). Journal of Parasitology 100: 646-650. doi: 10.1645/13-349.1

Jiménez-Quirós, O.; and Arroyo-Sancho, G. 1960. Helmintos de la República de Costa Rica. XV. Nematoda 3. Presencia de Litomosoides peñai n. sp. en Hemiderma perspicillata aztecum (Saussure, 1860). Revista de Biología Tropical 8: 63-67.

Juárez, G. V. (pers. comm.). Helmintos Parásitos de Leptonycteris yerbabuenae en Mina América, Tlaquiltenango, Morelos. Tesis de Licenciatura, Universidad Autónoma del Estado de Morelos, México.

Juárez, U. M. G. 2015. Helmintos parásitos de Pteronotus davyi (Chiroptera: Mormoopidae) en la Mina América, TlaquiItenango, Morelos. Tesis de Licenciatura, Universidad Autónoma del Estado de Morelos, México. 81 p.

Lamothe-Argumedo, R.; García-Prieto, L.; Osorio-Sarabia, D.; and Pérez-Ponce de León, G. 1997. Catálogo de la Colección Nacional de Helmintos. Universidad Nacional de Autónoma de México, Instituto de Biología, México. 211 p.

Lunaschi, L. I.; and Drago, F. B. 2011. A revision of Anenterotrema Stunkard, 1938 (Digenea: Anenterotrematidae) and key to its species. Zootaxa 2775: 50-64. 
Martínez, R. G. 2009. Helmintos parásitos de Tadarida brasiliensis (Chiroptera: Molossidae) en la Universidad Autónoma del Estado de Morelos, Campus Chamilpa, Cuernavaca. Tesis de Licenciatura, Universidad Autónoma del Estado de Morelos, México. 96 p.

Medellín, R. A. 2003. Diversity and conservation of bats in Mexico: Research Priorities, Strategies, and Actions. Wildlife Society Bulletin (1973-2006) 31: 87-97.

Moravec, F. 1982. Proposal of a new systematic arrangement of nematodes of the family Capillariidae. Folia Parasitologica, 29: 119V132.

Mühldorfer, K. 2013. Bats and bacterial pathogens: A Review. Zoonoses and Public Health 60: 93-103. doi: 10.1111/j.1863-2378.2012.01536.x

Ojeda, R. M. C. P. 2013. Helmintos parásitos de Balantiopteryx plicata (Chiroptera: Emballonuridae) en la Localidad Cruz Pintada, Mina América, Tlaquiltenango, Morelos. Tesis de Licenciatura, Universidad Autónoma del Estado de Morelos, México. $85 \mathrm{p}$.

Paredes-León, R.; García-Prieto, L.; Guzmán-Cornejo, C.; LeónRègagnon, V.; and Perez, T. M. 2008. Metazoan parasites of Mexican amphibians and reptiles. Zootaxa 1-139.

Peralta, J. L. 2009. Helmintos parásitos de Pteronotus parnellii en la cueva El Salitre, Emiliano Zapata, Morelos.Tesis de Licenciatura, Universidad Autónoma del Estado de Morelos, México. 100 p.

Peralta, J. L. 2012. Helmintos parásitos de los murciélagos más abundantes del estado de Morelos. Tesis de Maestría. Universidad Autónoma del Estado de Morelos, México. 199 p.

Peralta-Rodríguez, J. L.; Caspeta-Mandujano, J. M.; and Guerrero, J. A. 2012. A new spirurid (Nematoda) parasite from mormoopid bats in Mexico. Journal of Parasitology 98: 1006-1009, doi: 10.1645/GE-2993.1

Pérez-Ponce de León, G.; León-Regagnon, V.; and García-Vargas, F. 1996. Helminth parasites of bats from the Neotropical Region of Mexico. Bat Research News. 37: 1-6.

Presley, S. J.; Dallas, T.; Klingbeil, B. T.; and Willig, M. R. 2015. Phylogenetic signals in host-parasite associations for Neotropical bats and Nearctic desert rodents. Biological Journal of the Linnean Society 116: 312-327. doi: 10.1111/ bij.12601

Ramírez, C. S. B. 2015. Helmintos parásitos de Myotis velifer (Chiroptera: Vespertilionidae) en la cueva El Salitre, Xochitepec, Morelos. Tesis de Licenciatura. Universidad Autónoma del Estado de Morelos, México. 103 p.

Ramírez, D. S. E. 2015. Helmintos parásitos de Mormoops megalophylla (Chiroptera: Mormoopidae) en la Localidad de Mina América, Tlaquiltenango, Morelos. Tesis de Licenciatura, Universidad Autónoma del Estado de Morelos, México. $139 \mathrm{p}$.

Rodriguez-Ortiz, B.; Garcia-Prieto, L.; and de Leon, G. P. P. 2004 Checklist of the helminth parasites of vertebrates in Costa Rica. Revista de Biologia Tropical 52: 313-353.

Rojas, A.; and Guerrero, R. 2007. Capillaria sp., aislado de Desmodus rotundus (Chiroptera: Phyllostomidae) en Costa Rica. Mastozoología Neotropical 14: 101-102.
Rzedowski, J. 2006. Vegetación de México. Mexico City, Mexico. Salgado-Maldonado, G. 2006. Checklist of helminths parasites of freshwater fishes from Mexico. Zootaxa 1324: 1-357.

Santibáñez-López, C. E.; Francke, O. F.; Ureta, C.; and Possani, L. D. 2016. Scorpions from Mexico: From species diversity to venom complexity. Toxins 8: 1-18. doi: 10.3390/ toxins 8010002

Santos, C. P.; and Gibson, D. I. 2015. Checklist of the helminth parasites of South American bats. Zootaxa 3937: 471-499. doi: 10.11646/zootaxa.3937.3.3

Sarukhán, J.; Koleff, P.; Carabias, J.; Soberón, J.; Dirzo, R.; Llorente-Bousquets, J.; Halffter, G.; González, R.; March, I.; Mohar, A.; Anta, S.; and Maza, J. d. I. 2009. Síntesis: Conocimiento actual, evaluación y perspectivas de sustentabilidad. Capital natural de México. Comisión Nacional para el Conocimiento y Uso de la Biodiversidad, Mexico City, México. 100 p.

Sikes, R. S.; Gannon, W. L.; and the Animal Care and Use Committee of the American Society of Mammalogists. 2011. Guidelines of the American Society of Mammalogists for the use of wild mammals in research. Journal of Mammalogy 92: 235-253. doi: 10.1644/10-MAMM-F-355.1

Stunkard, H. W. 1938. Parasitic flatworms from Yucatan. In Fauna of the caves of Yucatan, A. S. Pearse (ed.). Carnegie Institution of Washington, Washington, D.C., 33-50 p.

Tapia, O. M. 2011. Helmintos parásitos de Balantiopteryx plicata en la Reserva de la Biosfera Sierra de Huautla. Tesis de Licenciatura. Universidad Autónoma del Estado de Morelos, México, $63 \mathrm{p}$.

Trejo-Salazar, R. E.; Scheinvar, E.; and Eguiarte, L. E. 2015. Who really pollinates agaves? Diversity of floral visitors in three species of Agave (Agavoideae: Asparagaceae). Revista Mexicana de Biodiversidad 86: 358-369. doi: 10.1016/j. rmb.2015.04.007

Ubelaker, J. E.; Specian, R. D.; and Duszynski, D. W. 1979. Endoparasites. Special Publications of the Museum, Texas Tech University, 16: 7-56.

Vaucher, C.; and Durette-Desset, M. C. 1986. Trichostrongyloidea (Nematoda) parasites de chiroptères néotropicaux. 1. Websternema parnelli (Webster, 1971) n. gen. n. comb and Linustrongylus pteronoti n. gen. n. sp. parasites de Pteronotus au Nicaragua. Revue Suisse de Zoologie 93: 237-246.

Vaucher, C.; and Durette-Desset, M. C. 1999. Histiostrongylus spineus n. sp. (Nematoda: Trichostrongylina), parasite de Phyllostomus discolor (Chiroptera: Phyllostomidae) et nouvelles données sur les genres Histiostrongylus Molin, 1861 and Parahistiostrongylus Perez Vigueras, 1941. Revue Suisse de Zoologie 106: 611-620. doi: 10.5962/bhl. part.80097

Wilson, D. E.; and Reeder, D. M. 2005. Mammal species of the world: A taxonomic and geographic reference. 3rd. ed. Johns Hopkins University Press, Baltimore, MD. 2,142 p.

Wolfgang, R. W. 1956. An additional note on the distribution of Biacantha desmoda. Canadian Journal of Zoology 34: 209. 

